\title{
Microalgae and bacteria dynamics in high rate algal ponds based on modelling results: long-term application of BIO_ALGAE model
}

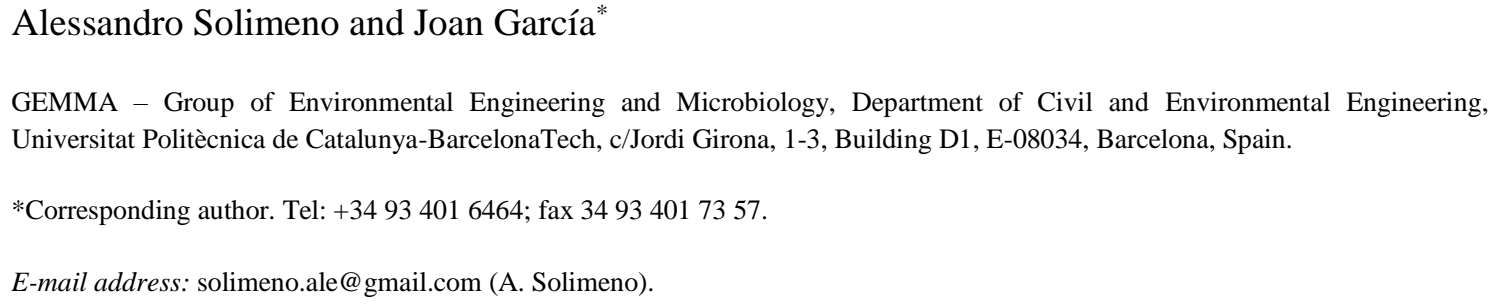

\section{Introduction}

High rate algal pond (HRAP) technology for wastewater treatment was developed in California by Prof. Oswald in the 1950s as an alternative to conventional waste stabilisation ponds (WPS) (Oswald and Gotaas, 1957). The smaller footprint of HRAP systems coupled with the benefit of production of valuable products (e.g. biofuels, bioplastics) from microalgae feedstock makes them more attractive over WPS (García et al. 2000a; Faleschini et al. 2012).

HRAPs are based on microalgae and bacteria interactions in wastewater exposed to light. Microalgae photosynthesis provides oxygen necessary for the degradation of organic compounds present in wastewater by aerobic bacteria. During bacterial oxidation of organic matter, carbon dioxide $\left(\mathrm{CO}_{2}\right)$ is produced and is available for both photosynthesis and nitrification (Oswald 1988). The many processes that occur in microalgae-bacteria systems are quite difficult to control (García et al. 2006; Awuah 2006; Fuentes et al. 2016). Moreover, these processes depend on ever-changing environmental variables such as solar radiation and temperature.

Although these systems have been studied for many years, still today the physical, chemical and biochemical reactions that occur in microalgae-bacteria systems 
are less well known than processes in conventional technologies, such as activated sludge. In fact, it is still very challenging to understand which are the main factors affecting microorganisms growth and production (i.e. microalgae and bacteria), and how their interactions affect the relative proportion of microorganisms. Recently, variations of biomass production over a year in pilot-scale HRAPs were experimentally evaluated by Mehrabadi et al. (2016). These authors observed that changes in microalgae concentration were clearly linked to seasonal fluctuations in temperature and light intensity in the absence of nutrient limitation. Other studies have shown that HRAP operating conditions play an important role on biomass composition, and of course the efficiency for removing pollutants. In a study conducted by Park and Craggs (2011), hydraulic retention time (HRT) clearly influenced microalgae proportion dynamics. A low hydraulic retention time (HRT, 2 days) yielded much more microalgae biomass than bacteria ( $80 \%$ of average of total biomass), while high HRT (8 days) had lower microalgae proportion ( $56 \%$ of average of total biomass). Note that these authors estimated microalgae proportion indirectly by measurements of chlorophyll-a concentration. At present time is not trivial to have a direct measure of microalgae and bacteria proportion in such mixed cultures.

Mathematical models have proven to be useful tools to understand and optimize the functioning of biological wastewater treatment systems, including microalgaebacteria systems (Park and Craggs 2011; Zhou et al. 2014). Solimeno et al. (2017a) developed the mechanistic BIO_ALGAE model to understand the internal functioning of complex microalgae-bacteria systems. One relevant feature of the model is that it allows microbial biomass concentration prediction, and thus evaluation of the relative proportions of microorganisms (Solimeno et al. 2015; 2017a; 2017b). 
52 ASM3 model (Iacopozzi et al. 2007) (International Water Association, IWA) were selected to describe microalgae and bacteria processes, respectively. Inorganic carbon as a limiting substrate for the growth of microalgae is one of the major innovative processes of BIO_ALGAE. Moreover, temperature, photorespiration, pH dynamics, solar radiation, light attenuation and rate of transfer of gases to the atmosphere are considered main limiting factors for microalgae growth. BIO_ALGAE was implemented in the COMSOL Multiphysics ${ }^{\mathrm{TM}}$ software, which solves differential model equations using the finite elements method (FEM). This model was previously calibrated and validated with high quality experimental data from duplicated pilot HRAPs receiving real wastewater (Solimeno et al. 2017a). Calibration was conducted by adjusting the following 6 parameters selected after a Morris's sensitivity analysis: 3 parameters related to microalgae and heterotrophic bacteria specific growth rate and decay of heterotrophic bacteria, and 3 parameters related to the transfer of gases to the atmosphere. These parameters were carefully calibrated and validated in our previous work comparing field data over 4 intensive days of experiments to predict daily fluctuations of the components in the ponds, and the relative proportions of microalgae and bacteria in a short-time scale. A long-term validation is essential to demonstrate (1) the capacity of the model to predict seasonal variations of microalgae and bacteria biomass, and (2) the effect of different HRT operating strategies on the HRAP performance, biomass production and biomass proportions.

Therefore, the aim of the present study is to validate the BIO_ALGAE model with experimental data from a pilot HRAP gathered during two different seasons (summer and winter), and operating at different HRT (4 and 8 days). Moreover, the 
potential of the model is demonstrated by means of practical study cases in which microalgae production, the relative proportion of microalgae and bacteria, and the ammonium removal efficiency were compared over an annual cycle. Hence, the purpose of this study was to study HRT and season effects on HRAP performance: microalgae production, the relative proportion of microalgae to bacteria, and ammonium removal efficiency.

\section{Material and methods}

\subsection{Experimental data}

The data used for simulations were obtained from previous studies conducted by the authors in a pilot HRAP (García et al. 2000a; 2002). A detailed description of the system can be found in these studies. In brief, the pilot HRAP was installed outdoors on the roof of the Group of Environmental Engineering and Microbiology (GEMMA) building (Universitat Politècnica de Catalunya-BarcelonaTech, Barcelona, Spain, latitude: $41^{\circ} 23^{\prime} 24.7380^{\prime \prime} \mathrm{N}$; longitude: $\left.2^{\circ} 9^{\prime} 14.4252^{\prime \prime} \mathrm{E}\right)$. The data used in this study were collected from July 1993 to October 1993 (Period I), and from November 1993 to February 1994 (Period II), corresponding to low and high HRT of the pilot (4 and 8 days, referred as $\mathrm{HRAP}_{4 \mathrm{~d}}$ and $\mathrm{HRAP}_{8 \mathrm{~d}}$, respectively). In practice, low HRT is used in warmer periods (summer-autumn), while high HRT are used in colder periods (autumnwinter) to maintain stable contaminant removal efficiencies (García et al. 2006).

The pilot HRAP was a typical race track built in PVC with a water surface area of $1.54 \mathrm{~m}^{2}$ and a water depth of $0.34 \mathrm{~m}$, and a nominal volume of $0.47 \mathrm{~m}^{3}$ (Fig. 1). A single paddlewheel was set to provide a rotational speed of $5 \mathrm{rpm}$ and a mid-channel 
velocity of approximately $9 \mathrm{~cm} \mathrm{~s}^{-1}$, avoiding biomass settling. HRAP received primary treated urban wastewater from a near street sewer, which was continuously pumped to the pond. Primary treatment was conducted in a $0.5 \mathrm{~m}^{3}$ storage tank. HRT of the HRAP was controlled by wastewater flow.

Samples of HRAP influent, HRAP mixed liquor (identical to HRAPs effluent, because of almost perfect complete mixing) were taken once a week, at 2:00 $\mathrm{PM} \pm 1$ hour. Description of the methods used for analyses can be found in García et al. (2000a, 2002). Water temperature, $\mathrm{pH}$ and DO (dissolved oxygen) were measured weekly, at 9:00 $\mathrm{AM} \pm 1$ and at 2:00 $\mathrm{PM} \pm 1$ hour. Maximum and minimum water temperature and irradiance recorded over the two periods investigated are shown in Table 1a.

Irradiance and air temperature were obtained from a nearby meteorological station.

\subsection{Model implementation}

Simulations were conducted using the BIO_ALGAE model. A detailed description of the components, the biokinetic processes, and the chemical and physical equations were presented in our previous works (Solimeno et al. 2015; 2017a; 2017b). To simplify presentation of the simulation results, Tables S1 and S2 in Supplementary Material (SM) present the biokinetic processes and the matrix of stoichiometric parameters. Values of biokinetic, physical and chemical parameters are shown in SM, Tables S3-S4. Mathematical expressions of the stoichiometric coefficients of each process are also shown in SM, Table S5. 

simplified 1D domain was used to represent a vertical section of the pilot HRAP. Assuming that each section behaves similarly due to perfect mixing of culture medium, this reasonable simplification allowed a reduction of computational cost. The culture was mixed with the paddlewheel, which ensured almost complete stirred reactor behaviour due to the small volume of the high rate pond in relation with the big size of the blades of the paddlewheel.

According to the Beer-Lambert law, irradiance decays exponentially as it passes through the HRAP mixed liquor. Therefore, a depth-averaged irradiance $\mathrm{I}\left[\mu \mathrm{mol} \mathrm{m} \mathrm{m}^{-2} \mathrm{~s}^{-1}\right]$ was used to represent irradiance at any point of the pond (Solimeno et al. 2017a). The penetration pathway corresponded to the depth of the $\operatorname{HRAP}(0.3 \mathrm{~m})$.

\subsection{Validation procedure}

BIO_ALGAE includes 93 parameters describing microalgae, bacteria, physical and chemical processes (Tables S3-S4, SM). Most of these parameters were obtained 137 from the existing RWQM1 [15], ASM1, and ASM3 models (Henze et al. 2000; Iacopozzi et al. 2007). Parameters related to temperature, photorespiration, carbon limitation and light attenuation were obtained from other literature cited in SM (Table S3-S4). Morris uncertainty method was applied in our previously work (Solimeno et al. 2016; 2017a) to identify the parameters which had the greatest influence on the

142 simulation response (Morris 1991). Results from our previous works have shown that the values of maximum growth rate of microalgae $\left(\mu_{\mathrm{ALG}}\right)$, the maximum growth rate and the decay of heterotrophic bacteria $\left(\mu_{\mathrm{H}}\right.$ and $\left.\mathrm{k}_{\text {death,H}}\right)$ and the parameters related to the 
transfer of gases to the atmosphere $\left(\mathrm{K}_{\mathrm{a}, \mathrm{O} 2}, \mathrm{~K}_{\mathrm{a}, \mathrm{CO} 2}\right.$ and $\left.\mathrm{K}_{\mathrm{a}, \mathrm{NH} 3}\right)$, were very sensitive and need to be calibrated in each application of the model (Solimeno et al. 2015; 2016).

In the present work, these parameters were set based on a previous calibration and validation effort using experimental data from duplicate HRAPs located at the Delhi wastewater pond treatment plant (California) during 4 days of experiments (Solimeno et al. 2017a). Results of this earlier effort indicated that the model was able to match experimental data accurately. Influent HRAP average concentrations observed in each experimental period were used as constant input values to run simulations (Table 1b). Influent concentrations of nitrate and nitrite were lower than the analytical method's detection limit and therefore considered to be zero in the input for the model. Ammonium nitrogen comprised almost $90 \%$ of dissolved Kjeldahl nitrogen (García et al. 2000a), and therefore the concentration of organic nitrogen present in the influent wastewater was omitted from the model.

Fractions of influent chemical oxygen demand (COD) were estimated from rational values for primary effluents in Activated Sludge Model No1 (ASM1) (Henze et al. 2000). Accordingly, the proportion of each fraction was defined as: $22 \%$ readily biodegradable soluble organic matter $\left(\mathrm{S}_{\mathrm{S}}\right), 50 \%$ slowly biodegradable particulate organic matter $\mathrm{X}_{\mathrm{S}}, 10 \%$ inert soluble organic matter $\left(\mathrm{S}_{\mathrm{I}}\right), 8 \%$ inert particulate organic matter $\left(\mathrm{X}_{\mathrm{I}}\right)$ and $10 \%$ heterotrophic bacteria $\left(\mathrm{X}_{\mathrm{H}}\right)$. In the present work microalgae and bacteria biomass are transformed from COD to total suspended solids (TSS) assuming a ratio $\mathrm{COD} / \mathrm{TSS}=0.80$ (Khorasandi et al. 2014) in order to compare experimental and simulation results. Note that some authors apply different ratios, for example, Von Sperling (2007) found values of 1-1.5 in waste stabilization pond effluents. 

the beginning of the two experimental periods are shown and described in Table 2 . Unfortunately, the concentration of each particulate component $\left(\mathrm{X}_{\mathrm{ALG}}, \mathrm{X}_{\mathrm{S}}, \mathrm{X}_{\mathrm{I}}, \mathrm{X}_{\mathrm{H}}, \mathrm{X}_{\mathrm{AOB}}\right.$ and $\mathrm{X}_{\mathrm{NOB}}$ ) in the mixed liquor was not known (where $\mathrm{X}_{\mathrm{ALG}}$ is microalgae concentrations and $\mathrm{X}_{\mathrm{AOB}}, \mathrm{X}_{\mathrm{NOB}}$ are ammonium and nitrite oxidizing bacteria, respectively). quantified from initial TSS value (from M1 pond) based on previous simulation tests. This assumption also provided an initial relationship between $\mathrm{pH}$, dissolved oxygen, and nutrients (i.e. nitrogen and carbon). using graphs of the two periods (with different HRT). Tested components during validation were: $\mathrm{pH}$, dissolved oxygen $\left(\mathrm{S}_{\mathrm{O} 2}\right)$, bicarbonate $\left(\mathrm{S}_{\mathrm{HCO} 3}\right)$, ammonium $\left(\mathrm{S}_{\mathrm{NH} 4}\right)$, nitrate $\left(\mathrm{S}_{\mathrm{NO} 3}\right)$, nitrite $\left(\mathrm{S}_{\mathrm{NO} 2}\right)$ and TSS. Model data were compared to experimental data by the root mean square error (RMSE).

production forecasting over a year cycle

Practical case studies were conducted to evaluate the variations in biomass production and the relative proportion of microalgae and bacteria over a year cycle (from January to December). The experiments were conducted over an annual cycle in order to investigate the influence of different HRT operating strategies and seasonal variations of temperature and irradiance on the relative proportion of microalgae and bacteria, and biomass production over a year cycle. 
In these studies, we simulated the evolution of microalgae, bacteria and TSS concentrations starting from the initial mixed liquor concentration used for the validation of the model at the beginning of the month of February, and using average influent wastewater concentration showed in Table 3. In addition, ammonium and ammonia concentration $\left(\mathrm{S}_{\mathrm{NH} 4}+\mathrm{S}_{\mathrm{NH} 3}\right)$ were evaluated as indicators of removal efficiency because they are very sensitive to changes in the environmental conditions in HRAPs. According to European standard (European Council 1991), HRAP performance is suitable when the concentration of ammonium and ammonia in the effluent is lower than $10 \mathrm{gN} \mathrm{m}^{-3}$. Three scenarios were evaluated: 1) the HRAP operating at 4-day HRT (HRAP4d $)_{4}$ over the whole year; 2) the HRAP operating at 8-day HRT (HRAP $\left.{ }_{8 d}\right)$ over the whole year, and 3) the HRAP operating with different HRT, from April to September at 4-day HRT and from October to March at 8-day HRT (HRAP $8-4-8 d)$.

The standard method of changing HRT during different seasons to maintain removal efficiency was investigated according to the results of previous experimental research carried out in Barcelona (García et al. 2000b). Water temperature data taken weekly at 9:00 $\mathrm{AM} \pm 1$ hour, and at 2:00 $\mathrm{PM} \pm 1$ hour measured over the one-year monitoring period, and irradiance data from the meteorological station of physical department of University of Barcelona (around $2 \mathrm{~km}$ far from the pilot HRAP) were used to run simulations for study cases.

\section{Results and discussion}

In this section, first of all, air temperature and irradiance changes over the course of all experiments were showed in Fig.2. As can be seen temperature and irradiance 
were greater in Period I than in Period II. Also in Period I the general trend of temperature and irradiance was a progressive decrease from July to October, while changes in Period II were more subtle. Following, performance assessment of the model in predicting experimental data under different HRTs were presented.

\subsection{HRAP $_{4 d}$ validation (Period I)}

Figure 3 shows the results of the validation in the $\mathrm{HRAP}_{4 \mathrm{~d}}$ from July to October. Simulations were able to follow measured $\mathrm{pH}$ and $\mathrm{S}_{\mathrm{O} 2}$ trends during the whole experimental period (Fig. 3a-b). As can be seen, both variables have a daily oscillations pattern due mostly to microalgae photosynthetic activity. This trend is in agreement with previous simulation results obtained during calibration in our previous study (Solimeno et al. 2017a), and also with previous experimental studies (García et al. 2006). Simulated daily minimum and maximum values were generally higher and lower than values measured at 9:00 AM and 2:00 PM, respectively, because the peaks of microalgae activity do not necessary coincide with these hours. From simulations, pH values ranged from 7.4 to 10.1 , with an average of 8.5 , while $\mathrm{S}_{\mathrm{O} 2}$ concentration ranged from $0 \mathrm{gO}_{2} \mathrm{~m}^{-3}$ to $28.1 \mathrm{gO}_{2} \mathrm{~m}^{-3}$, with an average of $11.2 \mathrm{gO}_{2} \mathrm{~m}^{-3}$. It is possible to see how at the end of this period daily fluctuations of $\mathrm{pH}$ and $\mathrm{S}_{\mathrm{O} 2}$ were slightly smoother than at the beginning of the study. At night, $\mathrm{S}_{\mathrm{O} 2}$ concentration decreased to be usually less than $5 \mathrm{gO}_{2} \mathrm{~m}^{-3}$, and even in some few cases almost 0 due to the lack of photosynthesis and the intense microbial respiration.

Simulations followed the trend observed for measured $\mathrm{S}_{\mathrm{HCO} 3}, \mathrm{~S}_{\mathrm{NH} 4}, \mathrm{~S}_{\mathrm{NO} 3}$ and $\mathrm{S}_{\mathrm{NO} 2}$ with different degree of success (Fig. 3c-f). Simulated $\mathrm{S}_{\mathrm{HCO} 3}$ and $\mathrm{S}_{\mathrm{NH} 4}$ curves 
matched quite well with the experimental data, and present a clear oscillation pattern mostly related to photosynthesis, with lower values of both variables during daytime. Microalgae grow during daytime using bicarbonate as carbon source, and subsequently $\mathrm{pH}$ raises favoring conversion of ammonium to ammonia, which is lost in part through volatilization. Moreover, microalgae uptake also contributes to ammonium decrease during daytime. These trends are also in agreement with simulation results carried out during calibration in our previous study (Solimeno et al. 2017a), and with previous experimental studies (García et al. 2006). Daily fluctuations of $\mathrm{S}_{\mathrm{HCO} 3}$ and $\mathrm{S}_{\mathrm{NH} 4}$ tend to soften towards the end of Period I (Fig 3c-d); the same pattern was observed for $\mathrm{pH}$ and So2. This is indicative of a lower photosynthetic activity due to decrease of incident irradiance and temperature.

As can be seen in Figure $\mathrm{S} 2 \mathrm{~d} \underline{\underline{3 d}}, \mathrm{~S}_{\mathrm{NH} 4}$ simulated concentrations were relatively low and constant during July and August (the first 60 days), and increased from midSeptember, corresponding with the decrease in incident irradiance and temperature. This also corresponds with the lower overall microalgae activity. Higher values of $\mathrm{S}_{\mathrm{NO}}$ and $\mathrm{S}_{\mathrm{NO} 2}$ were observed towards the end of the period, when $\mathrm{S}_{\mathrm{NH} 4}$ concentration was also higher. The model was able to simulate these trends described for $\mathrm{S}_{\mathrm{NO} 3}$ and $\mathrm{S}_{\mathrm{NO} 2}$ quite well, and it can be seen that photosynthesis influences these compounds much less due to the much lower daily oscillation trends.

Simulated TSS concentration fits experimental data with a good degree of concentration exhibits an oscillation trend, reflecting microalgae growth during daytime (crest) and decay at night (trough); heterotrophic bacteria concentration simulations do 
not exhibit this pattern. During the period, $X_{\mathrm{ALG}}$ gradually decreased, following the decreases in irradiance and temperature, while $\mathrm{X}_{\mathrm{H}}$ remained relatively constant. In July and August (the first 60 days), high irradiance and temperature produced a high photosynthetic activity, which at the same time produced high daily peaks of $\mathrm{S}_{\mathrm{O} 2}$ (often greater than $25 \mathrm{gO}_{2} \mathrm{~m}^{-3}$ ). Concentrations of DO in the culture above $250 \%$ air saturation (22.6 $\mathrm{gO}_{2} \mathrm{~m}^{-3}$ ) can dangerously inhibit microalgae activity (Costache et al. 2013). Subsequently these peaks seem to limit microalgae growth due to photorespiration. As can be seen in Figure $4 a$, the photorespiration factor $\left(\mathrm{fPR}_{\mathrm{PR}}\left(\mathrm{O}_{2}\right)\right)$ reduced microalgae growth from 20 to $40 \%$ (values of the factor from 0.8 to 0.6 , respectively). Thus, excess of oxygen caused less microalgae production that could had been avoided with improved oxygen transfer to the atmosphere. A detailed description of photorespiration factor is provided in SM. Also the drop in temperature from mid-September (day 65) had impact on $X_{\mathrm{ALG}}$, causing a reduction of growth between $\_10$ to $20 \%$ through the thermic photosynthetic factor $\left(\mathrm{f}_{\mathrm{T}_{-\mathrm{F}} \mathrm{FS}}\right.$ ) (Figure $4 \mathrm{~b}$ ) (see also $\mathrm{SM}$ for a detailed description of this factor).

Nitrifying bacteria $\left(\mathrm{X}_{\mathrm{AOB}}\right.$ and $\left.\mathrm{X}_{\mathrm{NOB}}\right)$ concentration was very low in comparison to $\mathrm{X}_{\mathrm{H}}$. This observation has already been reported in previous simulation studies, and for other types of wastewater treatment systems (Krasnits et al. 2009; Samsó and García 2013; Solimeno et al. 2017a)

Altogether, simulation results have predicted that much of the organic matter present in the mixed liquor corresponds to $\mathrm{X}_{\mathrm{ALG}}\left(55 \%\right.$ in average of TSS) and $\mathrm{X}_{\mathrm{H}}(26 \%$ in average of TSS). $\mathrm{X}_{\mathrm{AOB}}$ and $\mathrm{X}_{\mathrm{NOB}}$ are comparatively very low $(0.35 \%)$, and the remaining solids are attributable to $\mathrm{X}_{\mathrm{S}}(5.5 \%)$ and $\mathrm{X}_{\mathrm{I}}(13.2 \%)$. 
February. Again, the model exhibited the oscillation trend for $\mathrm{pH}$ and $\mathrm{S}_{\mathrm{O} 2}$ during the

292 whole experimental period (Fig. 5a-b), with lower values in comparison to Period I. The degree of model fit was slightly lower than in Period I. Simulation results indicated that $\mathrm{pH}$ values ranged from 7.2 to 9.6 , with an average of 8.1 , while $\mathrm{S}_{\mathrm{O} 2}$ concentrations ranged from $0.9 \mathrm{gO}_{2} \mathrm{~m}^{-3}$ to $20 \mathrm{gO}_{2} \mathrm{~m}^{-3}$ with an average of $11 \mathrm{gO}_{2} \mathrm{~m}^{-3}$. Daily fluctuations of $\mathrm{pH}$ and $\mathrm{S}_{\mathrm{O} 2}$ were shorter than in Period 1. In comparison to Period 1, nighttime $\mathrm{S}_{\mathrm{O} 2}$ concentration rarely decreased to below $5 \mathrm{gO}_{2} \mathrm{~m}^{-3}$ due to the lower overall microbial respiration and lower temperature (which increased transfer from the atmosphere to the mixed liquor).

Model validation results for $\mathrm{HRAP}_{4 \mathrm{~d}}$ conditions were comparable for $\mathrm{S}_{\mathrm{HCO} 3}, \mathrm{~S}_{\mathrm{NH} 4}$ and $\mathrm{S}_{\mathrm{NO} 2}$ data. Conversely, simulated $\mathrm{S}_{\mathrm{NO} 3}$ concentration did not match experimental data as closely as in Period I. Simulated $\mathrm{S}_{\mathrm{HCO}}$ and $\mathrm{S}_{\mathrm{NH} 4}$ exhibited the oscillation pattern already mentioned in Period I, but with shorter daily fluctuations, similar to the last part of Period I (when irradiance and temperature decreased). This is indicative of a lower overall photosynthetic activity in comparison to Period I. Much higher values of $\mathrm{S}_{\mathrm{NO} 2}$ were observed towards the end of Period II, when $\mathrm{S}_{\mathrm{NH} 4}$ was higher.

As can be seen in Figure 5g, the model was able to simulate TSS concentration with a good degree of accuracy. With respect to $\mathrm{HRAP}_{4 \mathrm{~d}}$, predicted concentrations of TSS, $\mathrm{X}_{\mathrm{ALG}}, \mathrm{X}_{\mathrm{H}}, \mathrm{X}_{\mathrm{AOB}}$ and $\mathrm{X}_{\mathrm{NOB}}$ were lower than the data (although HRT was higher

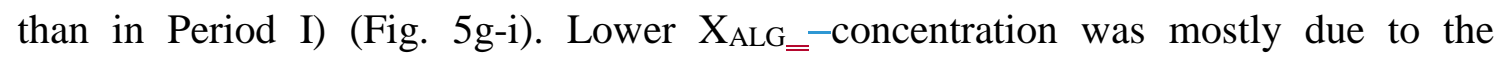
temperature (and to irradiance to a lesser extent). Figure $S 4 \mathrm{j}-5 \mathrm{j}$ shows reduction of 
312 growth from 10 to $30 \%$ through the thermic photosynthetic factor $\left(\mathrm{f}_{\mathrm{T}_{-} \mathrm{FS}}\right)$, and as can be seen was much lower in Period II than in Period I (compare with Fig. 4b). Although

314 COD influent in Period II $\left(195 \pm 50 \mathrm{~g} \mathrm{O}_{2} \mathrm{~m}^{-3}\right)$ was slightly higher than the in Period I

$315 \underline{\underline{\left(180 \pm 84 \mathrm{gO}_{2}\right.}} \underline{\left.\underline{\mathrm{m}^{-3}}\right), \mathrm{X}_{\underline{H}}} \underline{\underline{\text { concentration was lower due to the lower temperature. Bacteria }}}$

316 thermal factor ( $f_{\text {T,MB }}$ ) shows reduction of $\mathrm{X}_{\underline{\underline{H}}}$ growth from 40 to $60 \%$ (Fig. 5j).

$\mathrm{X}_{\mathrm{ALG}}$ was higher $\left(58 \%\right.$ in average of TSS) than $\mathrm{X}_{\mathrm{H}}(22 \%$ in average of TSS).

$\mathrm{X}_{\mathrm{AOB}}$ and $\mathrm{X}_{\mathrm{NOB}}$ biomass was comparatively much lower (2.4\%), but still higher than the estimated value for Period I. The remaining solids were attributable to $\mathrm{X}_{\mathrm{S}}(6 \%)$ and $\mathrm{X}_{\mathrm{I}}$ $(11.6 \%)$

A comparative evaluation indicates that HRT should be high enough to guarantee treatment performance and to prevent wash-out effects (Larsdotter 2006). Simulation results indicated that a higher HRT during the winter would probably be necessary than during the summer as result of the lower growth rate of microalgae as well as bacteria.

Table 4 presents the RMSE values obtained comparing the experimental data with the model simulations obtained from the validation of the model for each period investigated. Values of RMSE near zero indicate that the model fits experimental data well [28]. RMSE values for $\mathrm{pH}$, dissolved oxygen, bicarbonate, nitrogen species and total suspended solids are in good accordance with the RMSE values calculated during the calibration of the model (Solimeno et al. 2017a).

3.3. Study case: relative proportion of microalgae and bacteria, biomass production and ammonium removal efficiency of $H_{R A P_{4 d}}$ over a year cycle. 
In this case study, the relative proportion of microalgae and bacteria, and the production of microalgae are predicted with the HRAP operating continuously with 4day HRT. Figure 6a presents simulations of $X_{A L G}, X_{H}$ and TSS concentrations. $X_{A L G}$ was different between seasons, being lower in colder months (from November to March) and higher in warmer months (from April to October). The photorespiration effect limited microalgae growth during the warmer months, keeping the concentrations around $225 \mathrm{gTSS} \mathrm{m}^{-3} . \mathrm{X}_{\mathrm{H}}$ concentration was quite constant over the year due to the constant influent wastewater features. As can be seen from Figure $6 b$, microalgae proportion with respect to bacteria increased from April to October up to 60-75\% and dropped down to $27-33 \%$ from November to March. Trends suggested by these results are in accordance with the experimental studied by Park and Craggs (2011). In their study, the proportion of $\mathrm{X}_{\mathrm{ALG}}$ (estimated indirectly) in the microalgae-bacteria biomass of an HRAP operating at 4-day HRT with $\mathrm{CO}_{2}$ addition in summer was estimated to be around $80 \%$.

$\mathrm{X}_{\mathrm{ALG}}$ and TSS production are shown in Figure 6c. Predictions indicate that during the warmer month with a 4-day HRT, it is possible to reach up to $20 \mathrm{gTSS} \mathrm{m}^{-2} \mathrm{~d}^{-1}$ of $\mathrm{X}_{\mathrm{ALG}}$ production. Although $\mathrm{pH}$ values in summer are very high (> 9, Fig. 7a), the model indicates that microalgae are not carbon limited (carbon Monod function= 0.99). Furthermore, $\mathrm{S}_{\mathrm{O} 2}$ in excess limits microalgae growth through photorespiration (average $f_{\mathrm{PR}}\left(\mathrm{S}_{\mathrm{O} 2}\right)=0.62$ in summer $)($ Fig. $7 \mathrm{a})$.

Ammoniacal nitrogen concentration (sum of ammonium plus ammonia $\mathrm{S}_{\mathrm{NH} 4}+\mathrm{S}_{\mathrm{NH} 3}$, from now on "ammonium") was used as an indicator of efficiency of HRAP treatment wastewater. As can be seen in Figure $7 \mathrm{~b}, \mathrm{~S}_{\mathrm{NH} 4}$ has a clear seasonal pattern. In 
colder months, only approximately an average of $40 \%$ of the influent $\left(49 \mathrm{~g} \mathrm{~N}_{-} \mathrm{NH}_{4} \mathrm{~m}^{-3}\right)$ is removed, while in warmer months average removal rate goes up to $90 \%$.

\subsection{Study case: relative proportion of microalgae and bacteria, biomass} production and ammonium removal efficiency of HRAP8d over a year cycle.

In this case study, the HRAP is continuously operated with 8-day HRT. Figure 8a presents simulations of $\mathrm{X}_{\mathrm{ALG}}, \mathrm{X}_{\mathrm{H}}$ and TSS concentrations. $\mathrm{X}_{\mathrm{ALG}}$ changed less over the year in comparison to the $\mathrm{HRAP}_{4 \mathrm{~d}}$. $\mathrm{X}_{\mathrm{H}}$ concentrations were quite constant over the year, and had similar concentrations to $\mathrm{HRAP}_{4 \mathrm{~d}}$. As can be seen from Figure $8 \mathrm{~b}$, microalgae proportion in comparison to bacteria was higher from April to October (76$78 \%$ ), and slightly dropped down to $65-68 \%$ from November to March. In this case study, $X_{\mathrm{ALG}}$ were more abundant than $\mathrm{X}_{\mathrm{H}}$ over the entire year. These trends are not in agreement with the experimental study by Park and Craggs (2011), where the proportion of microalgae (estimated indirectly) of an HRAP operating at 8-days HRT with $\mathrm{CO}_{2}$ addition in summer was around $55.6 \%$, much lower than in a 4-day HRT. Park and Craggs (2011) indicated that microalgae growth was limited due to low light availability in the pond. Irradiance was attenuated by the high biomass concentration up to $430 \mathrm{~g} \mathrm{VSS} \mathrm{m}^{-3}$, while in our numerical experiment the biomass concentration in term of TSS is maintained below of $400 \mathrm{~g} \mathrm{TSS} \mathrm{m}^{-3}$.

$\mathrm{X}_{\mathrm{ALG}}$ and TSS production are compared in Figure 8c. Predictions indicate that with an 8-day HRT, it is possible to reach up to $10.6 \mathrm{~g} \mathrm{TSS} \mathrm{m}^{-2} \mathrm{~d}^{-1}$ of $\mathrm{X}_{\mathrm{ALG}}$ production in warmer months, which resulted $50 \%$ lower than $\mathrm{X}_{\mathrm{ALG}}$ production predicted in 4-day HRT. In this case study $\mathrm{pH}$ is also very high in summer (> 9, Fig. 9a), however the 
model indicates that microalgae are not carbon limited. Again, $\mathrm{S}_{\mathrm{O} 2}$ in excess limits microalgae growth through photorespiration (average $f_{\mathrm{PR}}\left(\mathrm{S}_{\mathrm{O} 2}\right)=0.42$ in summer) (Fig. 9b). Excess of $\mathrm{S}_{\mathrm{O} 2}$ was much higher than $\mathrm{HRAP}_{4 \mathrm{~d}}$. With an 8-day HRT the mass influent organic matter concentration in the pond is reduced, therefore oxygen demand by $\mathrm{X}_{\mathrm{H}}$ to oxidize organic matter is lower than oxygen produced by microalgae during the photosynthesis due to the high concentration of $\mathrm{X}_{\mathrm{ALG}}\left(260 \mathrm{gTSS} \mathrm{m}^{-3}\right.$.in summer). As can be seen in Figure 9c, the model prediction indicated that average ammonium removal rate goes up to $98 \%$ of the influent $\left(49 \mathrm{~g} \mathrm{~N} \_\mathrm{NH}_{4} \mathrm{~m}^{-3}\right)$ over the whole year.

\subsection{Study case: enhanced optimization of microalgae production and} ammonium removal efficiency over a year cycle

In this case study, the HRAP is operated with changing HRT. Higher HRT (8day) was used in the colder months (from October to March) and lower HRT (4-day) in the warmer months (from April to September) $\left(\mathrm{HRAP}_{8-4-8 \mathrm{~d}}\right)$. This strategy was selected from results obtained in the previous case studies.

Figure 10a presents simulations of $\mathrm{X}_{\mathrm{ALG}}, \mathrm{X}_{\mathrm{H}}$ and TSS concentrations. $\mathrm{X}_{\mathrm{ALG}}$ and microalgae/bacteria proportion (not shown, but can be deduced) changed slightly over the year in comparison by the other two case studies. $\mathrm{X}_{\mathrm{ALG}}$ production was enhanced (Fig. 10b). With HRAP ${ }_{8-4-8 d}$, the production increased to $30 \%$ and $35 \%$ in $\mathrm{HRAP}_{4 d}$ and $\operatorname{HRAP}_{8 \mathrm{~d}}$, respectively.

As can be seen in Figure 10c the model prediction indicated that average removal rate of ammonium goes up to $92 \%\left(49 \mathrm{~g} \mathrm{~N} \_\mathrm{NH}_{4} \mathrm{~m}^{-3}\right)$ over the whole year. 


\section{Conclusion}

408

409

410

411

412

413

414

415

416

417

418

419

420

421

422

423

424

425

426

\section{References}

data from a pilot HRAP operating at different HRT (4 and 8 days) during the summer and winter seasons (respectively). The model accurately matched HRAP dynamics using the calibrated values of 6 parameters obtained in previous work by the authors.

BIO_ALGAE has demonstrated by means of practical study cases to be a useful tool to understand microalgae and bacteria interactions in wastewater treatment, and in particular to study the effect of different HRAP operating strategies on the relative proportion of microalgae and bacteria, biomass production, and removal of ammonium.

Moreover, the model could be used to optimize biomass production. Moreover, the model was able to enhanced biomass production.

E-supplementary data of this work can be found in online version of the paper

\section{Acknowledgements}

The authors thank Jason Hale for the manuscript review. This research was supported by the Spanish Ministry of Economy and Competitiveness through the project DIPROBIO (CTM2012-37860). Alessandro Solimeno also acknowledges the FPUAP2012-6062 scholarship provided by the Spanish Ministry of Education and Science. 
Awuah, E., 2006. Pathogen removal mechanisms in macrophyte and algal waste stabilization ponds. Dissertation, UNESCO-IHE Institute, Delft

431

432

Bennett, N.D., Croke, B.F.W., Guariso, G., Guillaume, J.H.A., Hamilton, S.H., Anthony, A.J.,

Marsilli, S., Newham, L.T.H., Norton, J.P., Perrin, C., Pierce, A.S., Robson, B., Seppelt, R.,

Voinov, A.A., Fath, B.D., Andreassian, V., 2013. Characterising performance of environmental models. Environ Model Softw. 40:1-20

436

Bitog, J.P., Lee, I.B., Lee, C.G., Kim, K.S., Hwang, H.S., Hong, S.W., Seo, H.I., Kwon, K.S., 438

Mostafa, E., 2011. Application of computational fluid dynamics for modelling and designing photobioreactors for microalgae production: A review. Comput Electron Agric. 76(2):131-147

440

Costache, T.A., Acién Fernández, F.G., Morales, M., Fernández Sevilla, J.M., Stamatin, I.,

Molina, E., 2013. Comprehensive model of microalgae photosynthesis rate. Appl Microbiol

Dauta, A., Devaux, J., Piquemal, F., Boumnich, L., 1990. Growth rate of four freshwater algae in relation to light and temperatura. Hydrobiologia. 207:221-226

European Union, Council Directive 91/271/EEC concerning urban wastewater treatment (1991)

449

450

Faleschini, M., Esteves, J.L., Valero, M.C., 2012. The effects of hydraulic and organic loadings 451 on the performance of a full scale facultative pond in a temperate climate region (Argentine Patagonia). Water Air Soil Pollut. 223(5):2483-2493 
454 Fernández, I., Acién, F.G., Berenguel, M., Guzmán, J.L., Andrade, G.A., Pagano, D.J., 2014. A 455 Lumped parameter chemical-physical model for tubular photobioreactors. Chem Eng Sci. $112: 116-129$

457

Fuentes, J.L., Inés Garbayo, I., Cuaresma, M., Montero, Z., González-del-Valle, M., Vilchez, C., 2016. Impact of Microalgae-Bacteria Interactions on the Production of Algal Biomass and Associated Compounds. Mar Drugs. 14(5):100

461

García, J., Hernández-Mariné, M., Mujeriego, R., 2000a. Influence of phytoplankton 463 composition on biomass removal from high-rate oxidation lagoons by means of sedimentation and spontaneous Xocculation. Water Environ Res. 72:230-237

465

García, J., Mujeriego, R., Hernandez-Marine, M., 2000b. High rate algal pond operating strategies for urban wastewater nitrogen removal. Appl Phycol. 12:331-339

García, J., Hernández-Mariné, M., Mujeriego, R., 2002. Analysis of key variables controlling phosphorus removal in high rate oxidation ponds provided with clarifiers. Water SA. 28:1-8

471

472 García, J., Green, B.F., Lundquist. T., Mujeriego. R., Hernández-Mariné. M., Oswald, W.J., 473 2006. Long term diurnal variations in contaminant removal in high rate ponds treating urban 474 wastewater. Bioresour Technol. 97:1709-1715

475

476

Gujer, W., Henze, M., Mino, T., Van Loosdrecht, M., 1999. Activated Sludge Model No. 3.

477

Water Sci Techno. 39(1):183-193 
Henze, M., Gujer, W., Mino, T., Van Loosdrecht, M., 2000. Activated sludge models ASM1,

480

481

482

483

486

487

488

489

490

491

492

493

494

495

496

497

498

499

500

501

502

ASM2, ASM2d and ASM3. IWA Scientific and Technical Report No. 9, IWA Publishing, London, UK. 2000.

Iacopozzi, I., Innocenti, V., Marsili-Libelli, S., Giusti, E., 2007. A modified Activated Sludge Model No. 3 (ASM3) with two-step nitrification-denitrification. Environ Modell Softw. 22:847861

Khorsandi, H., Alizadeh, R., Tosinejad, H., Porghaffar, H., 2014. Analysis of nitrogenous and algal oxygen demand in effluent from a system of aerated lagoons followed by polishing pond. Water Sci Techno. 70:1-95

Krasnits, E., Friedler, E., Sabbah, I., Beliavski, M., Tarre, S., Green, M., 2009. Spatial distribution of major microbial groups in a well-established constructed wetland treating municipal wastewater. Ecol Eng. 35(7):1085-1089

Larsdotter, K., 2006. Wastewater treatment with microalgae - A literature review. Vatten. $62: 31-38$

Mehrabadi, A., Farida, M.M., Craggs, R., 2016. Variation of biomass energy yield in wastewater treatment high rate algal ponds. Algal Res. 15:143-151

Molina Grima, E., García Camacho, F., Sánchez Perez, J.A., Fernández Sevilla, J.M., Acién Fernández, F.G., Contreras Gómez, A., 1994. A mathematical model of microalgal growth in light limited chemostat culture. J Chem Tech Biotechnol. 61:167-173 
Morris, M.D., 1991. Factorial Sampling Plans for Preliminary Computational Experiments.

504 Technometrics. 33(2):161-174

505 Novak, J.T., Brune, D.E., 1985. Inorganic carbon limited growth kinetics of some freshwater 506 algae. Water Res. 19:215-225

507 Oswald, W.J., Gotaas, H.B., 1957. Photosynthesis in sewage treatment. Trans Am Soc Civ Eng.

509

510 Oswald, W.J., 1988. Microalgae and Wastewater Treatment, in Microalgal Biotechnology,

511 Borowitzka MA and Borowitzka LJ (eds). Cambridge University Press, New York, pp 357-94

512

513 Packer, A., Li, Y., Andersen, T., Hu, Q., Kuang, Y., Sommerfeld, M., 2011. Growth and neutral 514 lipid synthesis in green microalgae: a mathematical model. Bioresour Technol. 102:111-7

Park, J.B.K., Craggs, R.J., 2011. Nutrient removal in wastewater treatment high rate algal ponds with carbon dioxide addition. Water Sci Technol. 63(8):1758-1764

517

518 Reichert, P., Borchardt, D., Henze, M., Rauch, W., Shanahan, P., Somlyódy, L., Vanrolleghem, 519 P., 2001. River Water Quality Model no. 1 (RWQM1): II. Biochemical process equations. 520 Water Sci Techno. 43(5):11-30

521

522

Sah, L., Rousseau, D., Hooijmans, C.M., Lens, P., 2011 3D model for a secondary facultative 523 pond. Ecol Model. 222(9):1592-1603

524

525 Samsó, R., García, J., 2013. Bacteria distribution and dynamics in constructed wetlands based 526 on modelling results. Sci Total Environ. 461-462:430-440 (2013). 
528 Silva, H.J., Pirt, J., 1984. Carbon dioxide inhibition of photosynthetic growth of chlorella. J Gen

529 Microbiol. 130:2833-2838

530 Solimeno, A., Samsó, R., Uggetti, E., Sialve, B., Steyer, J.P., Gabarró, A., García, J., 2015. New

531 mechanistic model to simulate microalgae growth. Algal Res. 12:350-358

532

533 Solimeno, A., Samsó, R., García, J., 2016. Parameter sensitivity analysis of a mechanistic model

534 to simulate microalgae growth. Algal Res. 15:217-223

535

536 Solimeno, A., Parker, L., Lundquist, T., García, J., 2017a. Integral microalgae-bacteria model

537 (BIO_ALGAE): application to wastewater high rate algal ponds. Sci Total Environ. 601$538 \quad 601: 646-657$

539

540 Solimeno, A., Acién, F.G., García, J., 2017b. Mechanistic model for design, analysis, operation 541 and control of microalgae cultures: Calibration and application to tubular photobioreactors. 542 Algal Res. 21:236-246

543

544 Von Sperling, M., 2007. Waste stabilization ponds, IWA Pubblishing, London, Uk

$545 \mathrm{Wu}, \mathrm{X}$., Merchuk, J., 2001. A model integrating fluid dynamics in photosynthesis and 546 photoinhibition processes. Chem Eng Sci. 56:3527-3538

547 Zhou, X., Yuan, S., Chen, R., Song, B., 2014. Modelling microalgae growth in nitrogen-limited 548 continuous culture. Energy. 73:575-580 


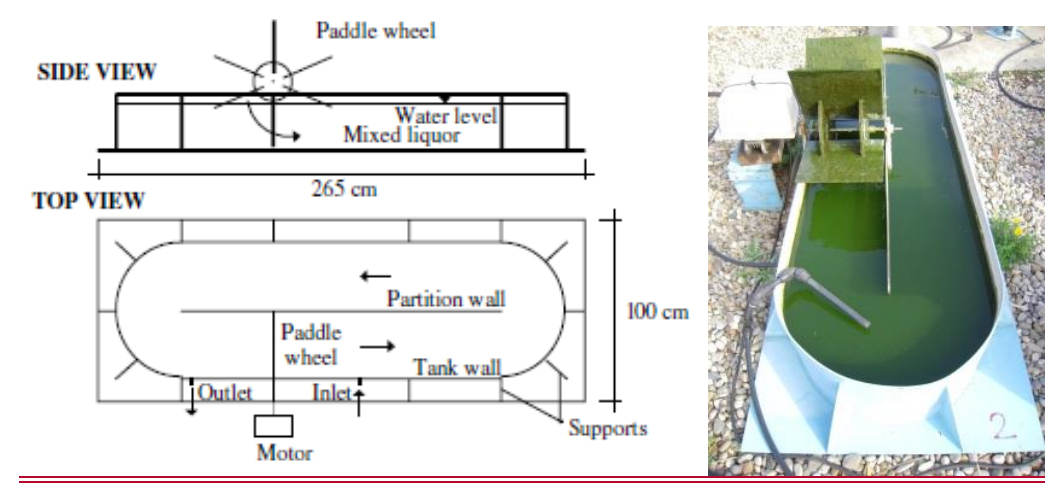

551

552 Fig. 1. Diagram of top and side views of the pilot HRAP on the left and a picture on the right. The system was 553 located roof of the Group of Environmental Engineering and Microbiology (GEMMA) building (Universitat 554 Politècnica de Catalunya-BarcelonaTech, Barcelona, Spain).



a)

Time [d]

b)

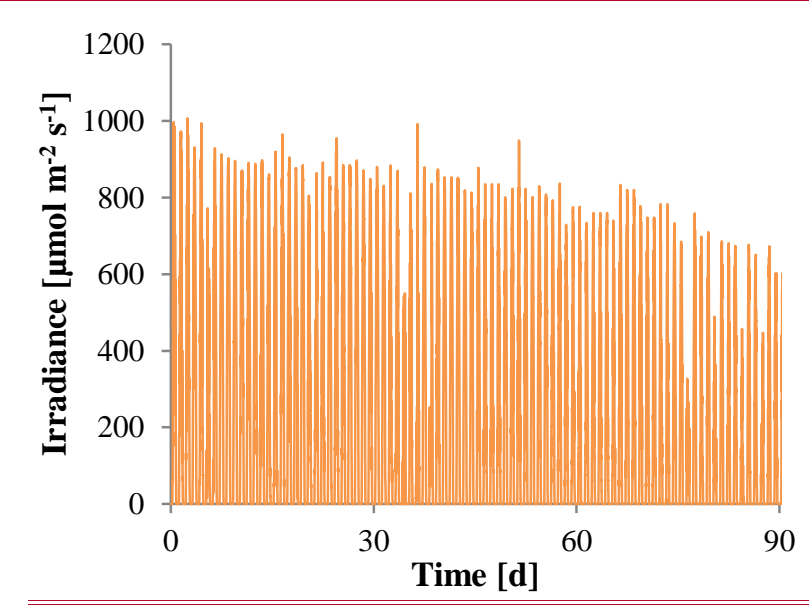




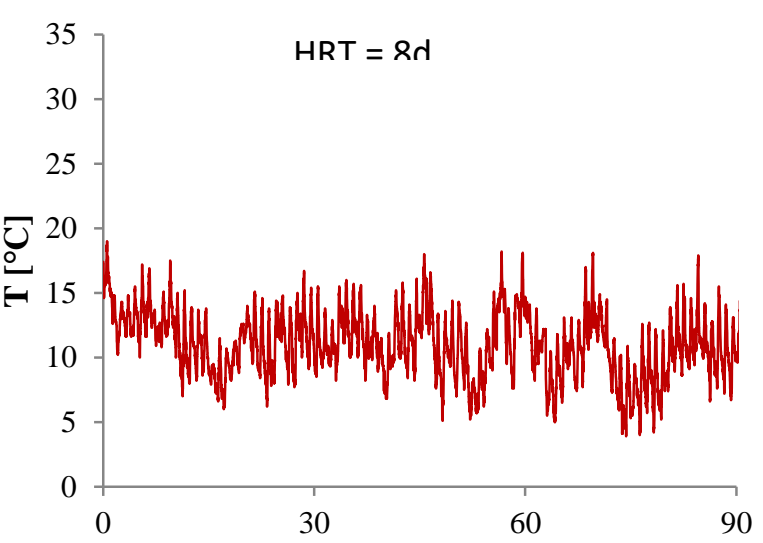

$H R T=8 d$

558

c)

Time [d]

c)

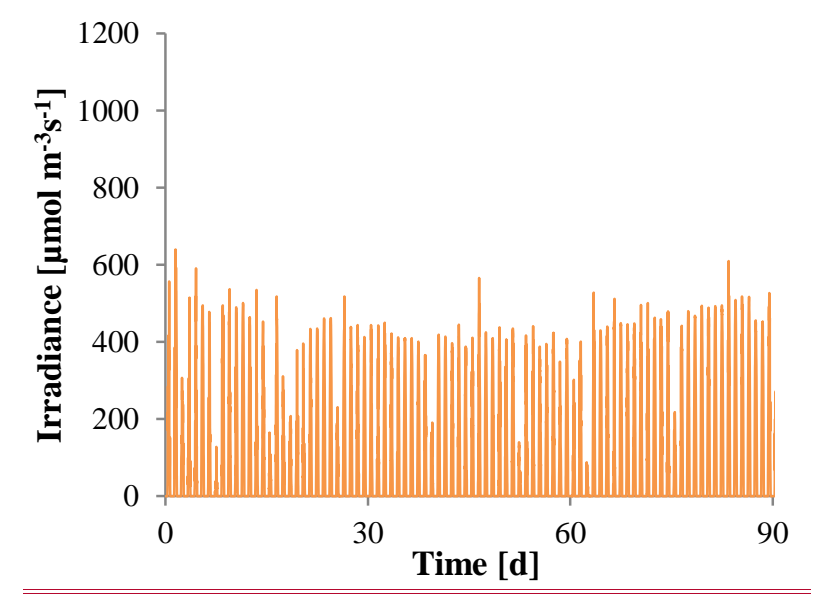

559

560 Fig. 2. Changes in air temperature and irradiance in Barcelona over Period I (July 21st - October 14th, 1993,

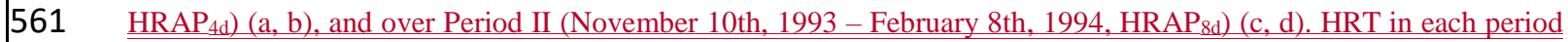
562 also shown. 


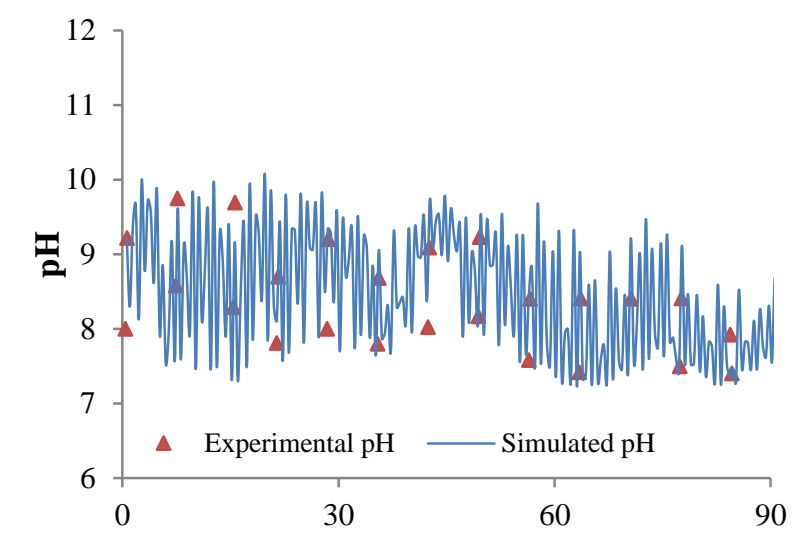

a) Time [d] b)

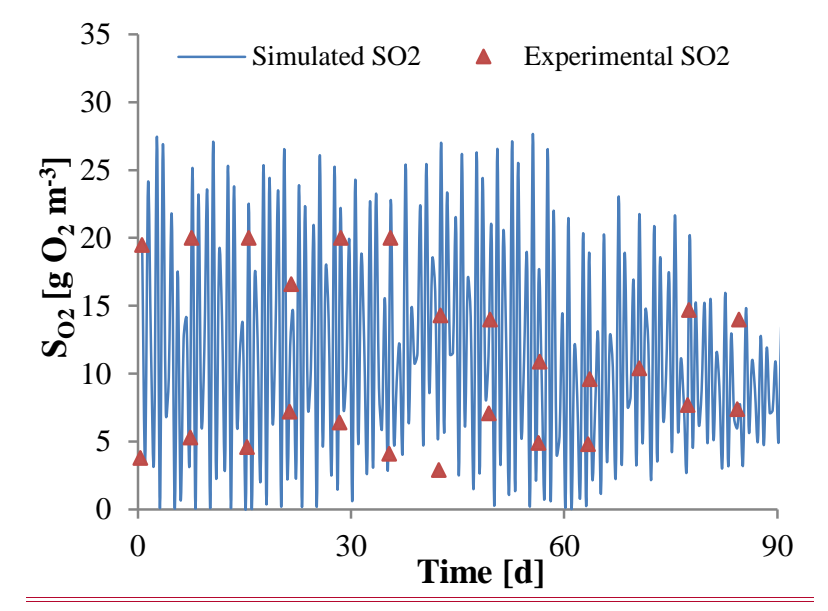




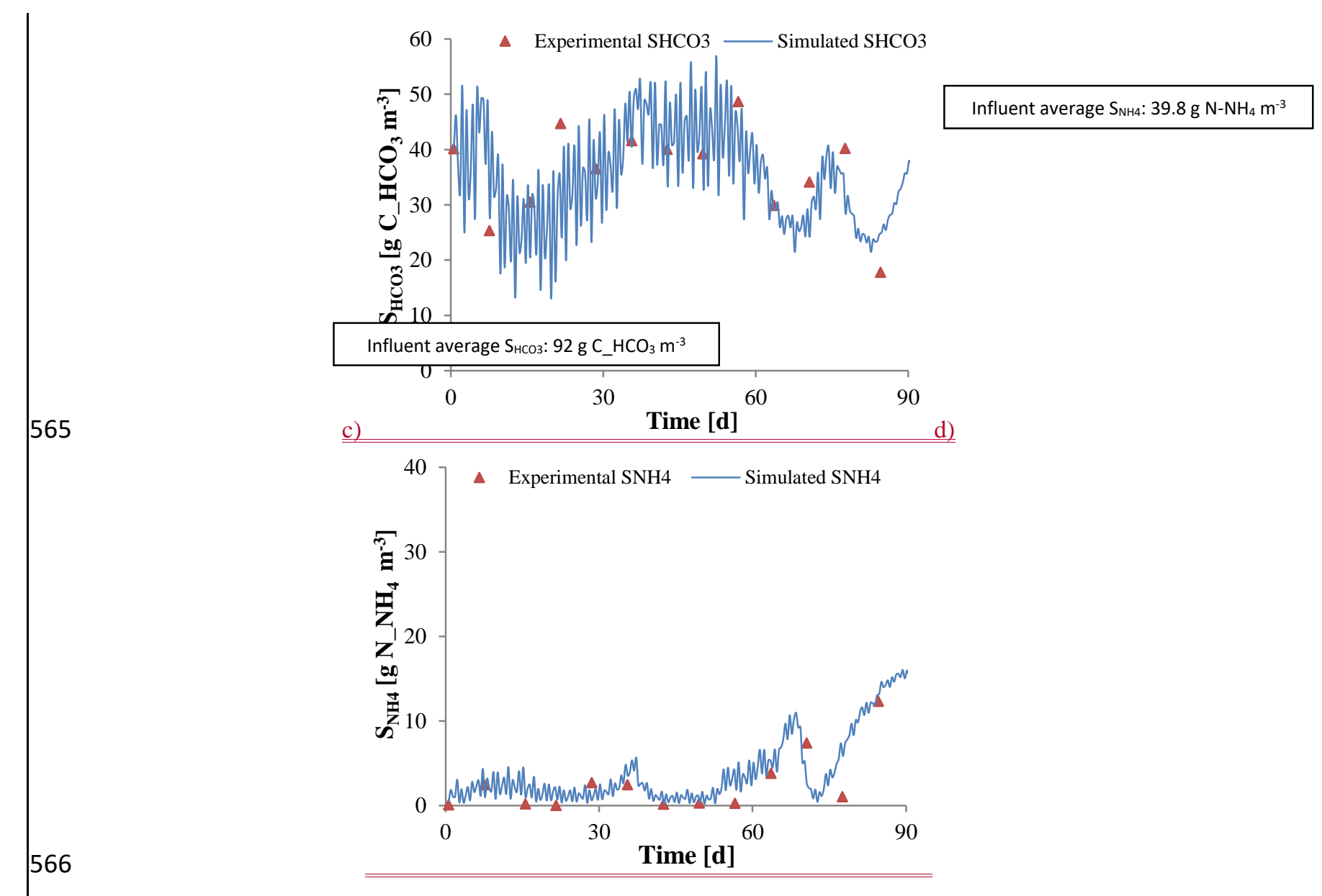



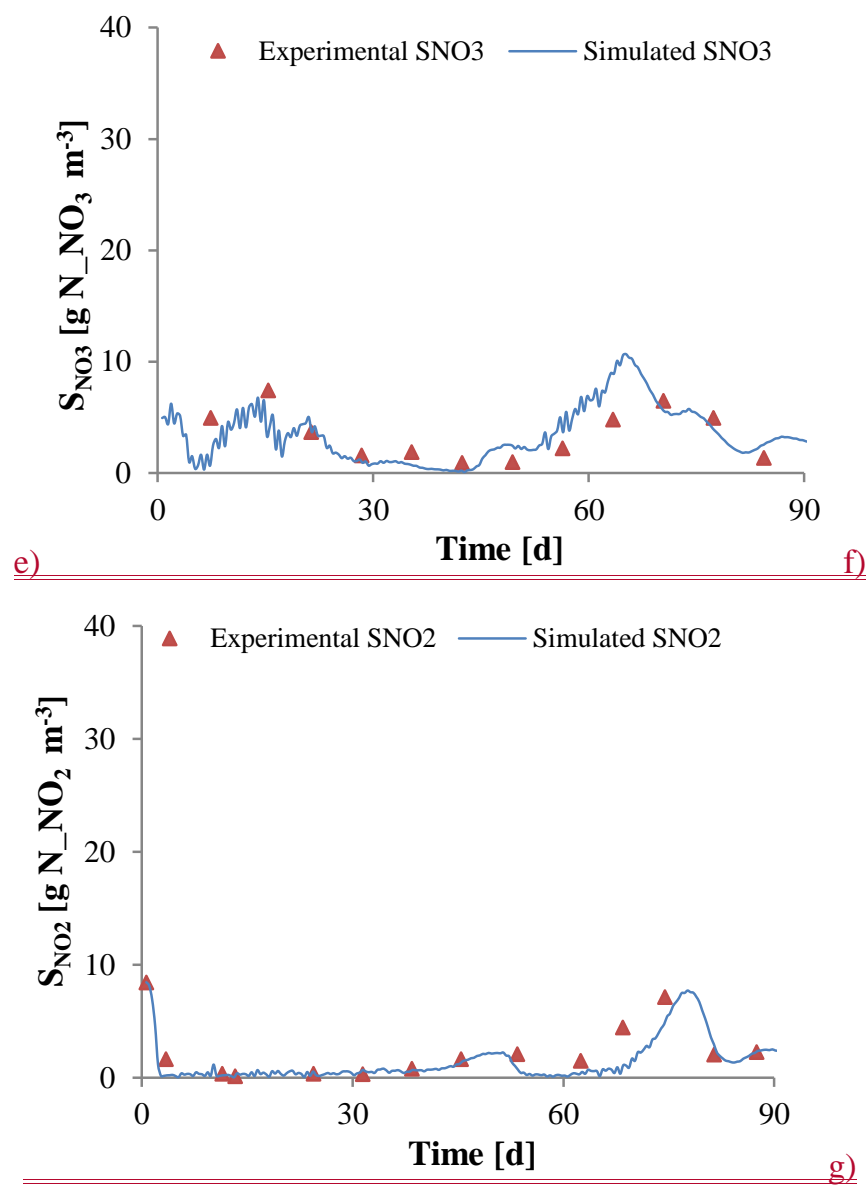

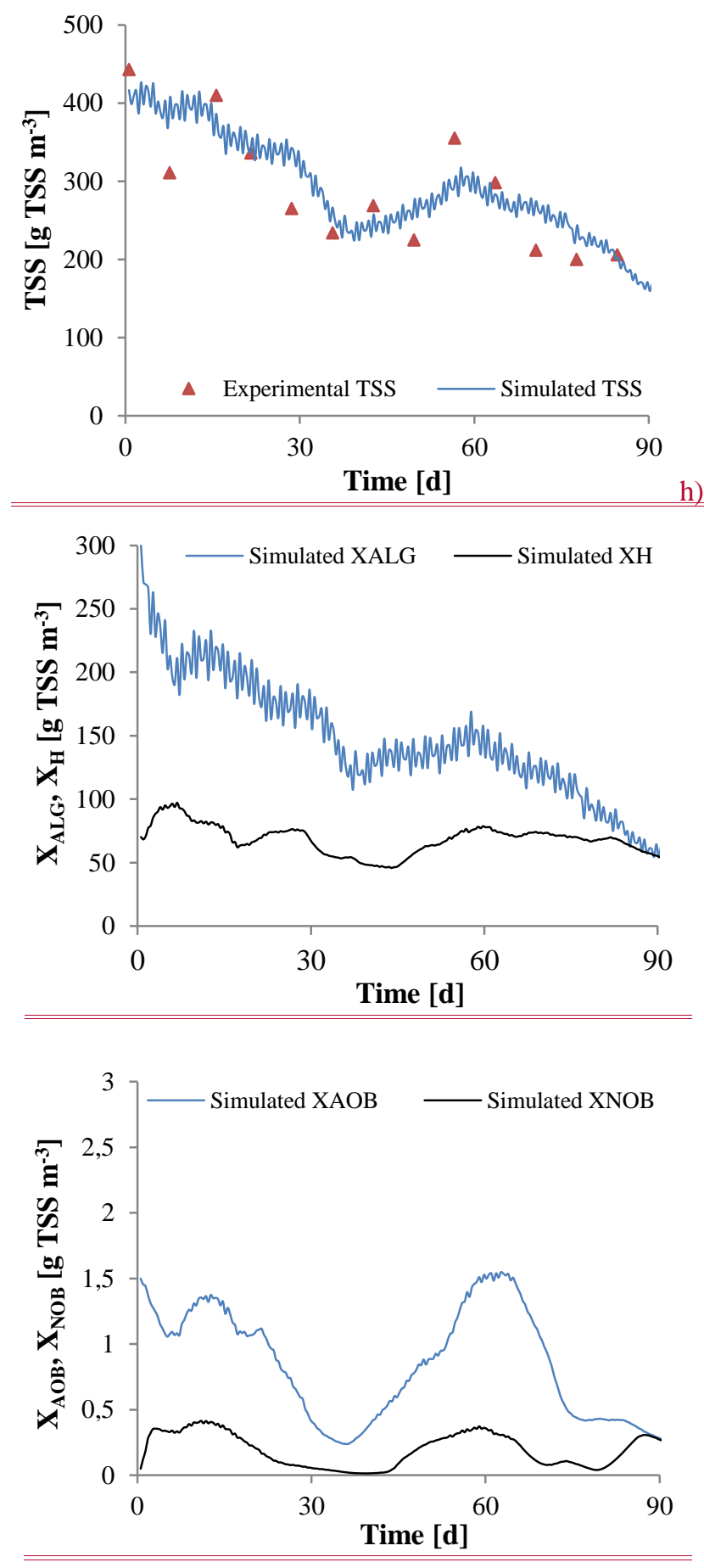

i)

573 Fig. 3. Changes in experimental (red triangles) and simulated (blue and black lines) a) pH, b) $\left.\left.\mathrm{S}_{\mathrm{O} 2}, \mathrm{c}\right) \mathrm{S}_{\mathrm{HCO} 3}, \mathrm{~d}\right) \mathrm{S}_{\mathrm{NH} 4}$,

574 e) $S_{\mathrm{NO} 3}$ f) $\left.\left.\mathrm{S}_{\mathrm{NO} 3}, \mathrm{~g}\right) \mathrm{TSS}, \mathrm{h}\right) \mathrm{X}_{\mathrm{ALG}}$ and $\mathrm{X}_{\mathrm{H}}$, and i) $\mathrm{X}_{\mathrm{AOB}} \mathrm{X}_{\mathrm{NOB}}$ concentrations over the Period I (July 21st - October $575 \quad$ 14th, 1993) in the HRAP 4 d. Note that in a) and b) values were measured at 9:00 AM \pm 1 hour and 2:00 PM \pm 1 hour.

576 All other values measured at 2:00 PM \pm 1 hour. Higher values of $\mathrm{pH}$ and Sozobserved at 2:00 PM \pm 1 hour. $\mathrm{S}_{\mathrm{NO3}}$ and 577 S 


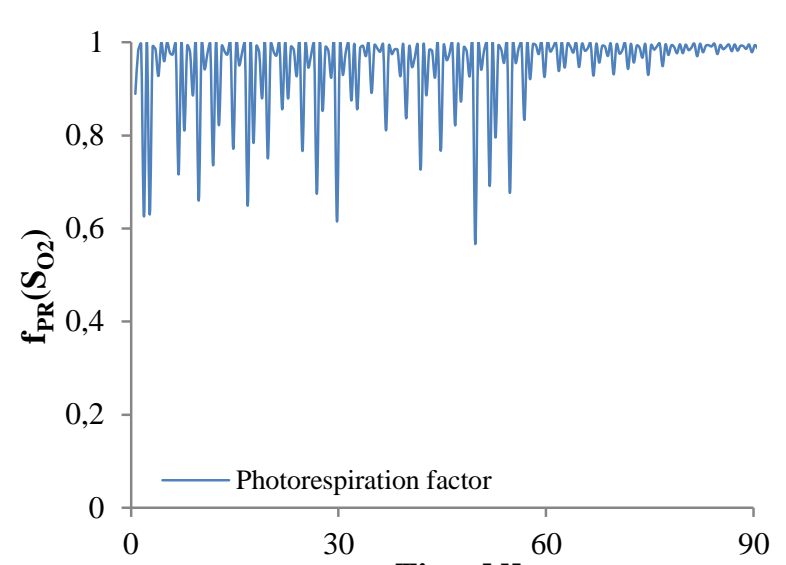

a) Time [d] b)

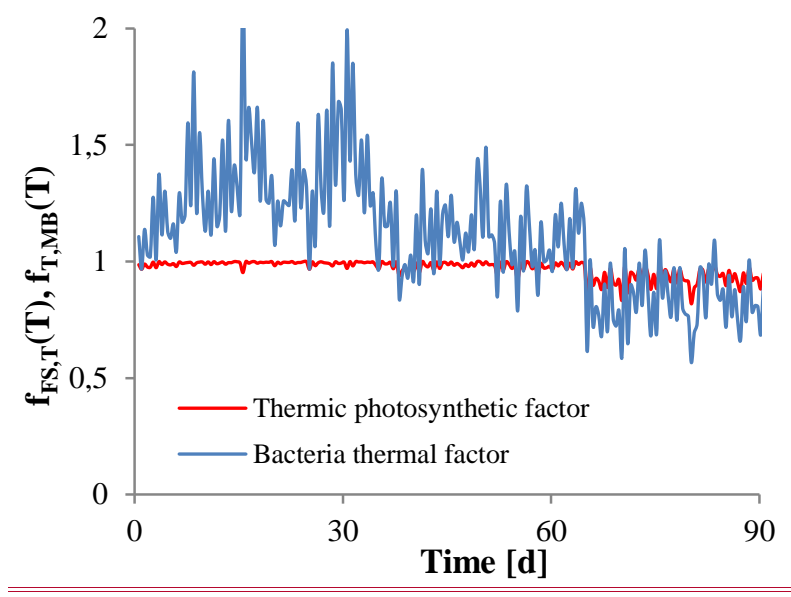

580 Fig. 4. a) Changes in the values of $\mathrm{fPR}_{\mathrm{PR}}\left(\mathrm{S}_{\mathrm{O} 2}\right)$ and b) $\mathrm{fFS}_{\mathrm{T}}(\mathrm{T})$ and $\mathrm{f}_{\mathrm{T}, \mathrm{MB}}(\mathrm{T})$ factors over Period I (July 21st - October 581 14th, 1993) in HRAP $_{4 \mathrm{~d}}$. 


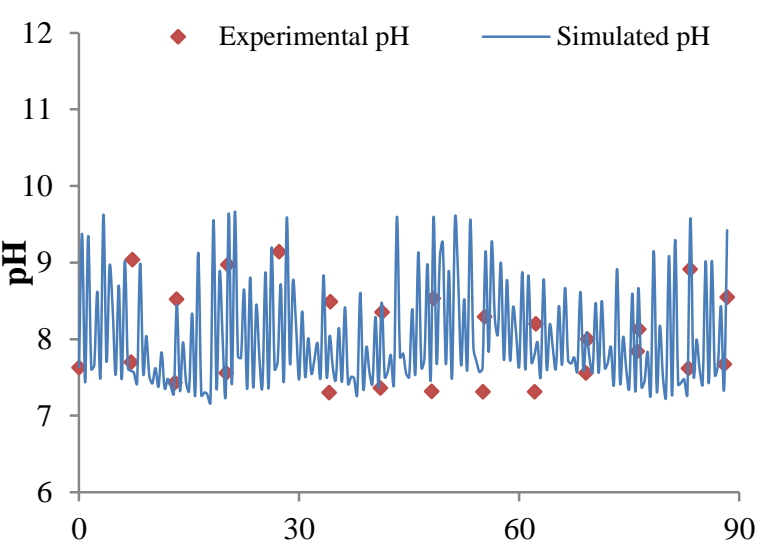

584

a)

Time [d]

b)






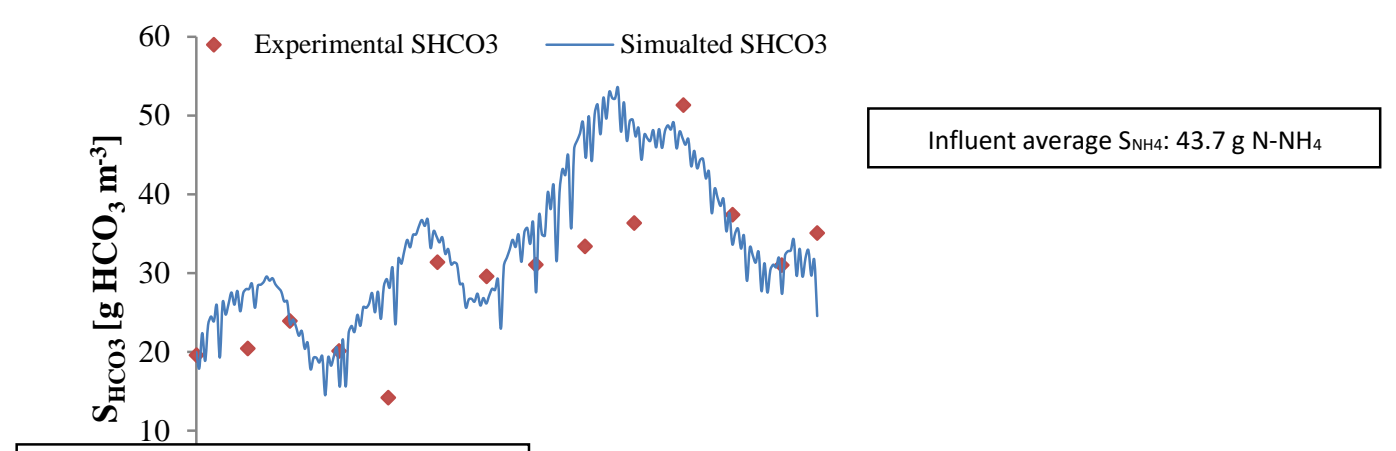

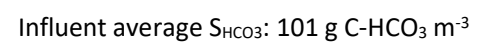

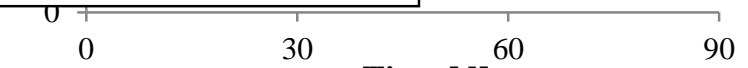

\begin{tabular}{llll} 
c) & Time [d] & d) \\
\hline \hline
\end{tabular}

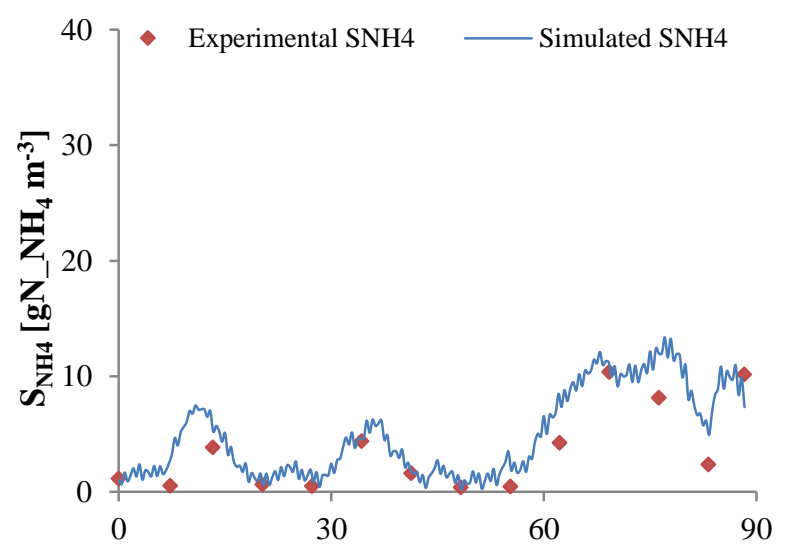




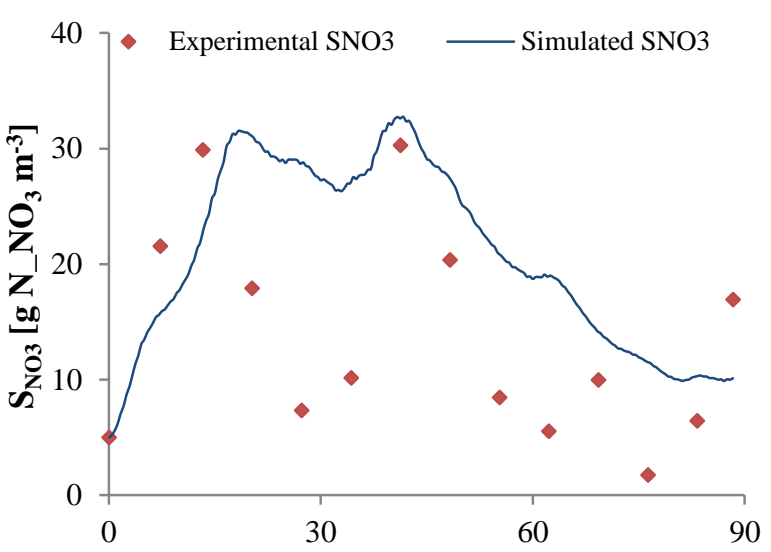

588

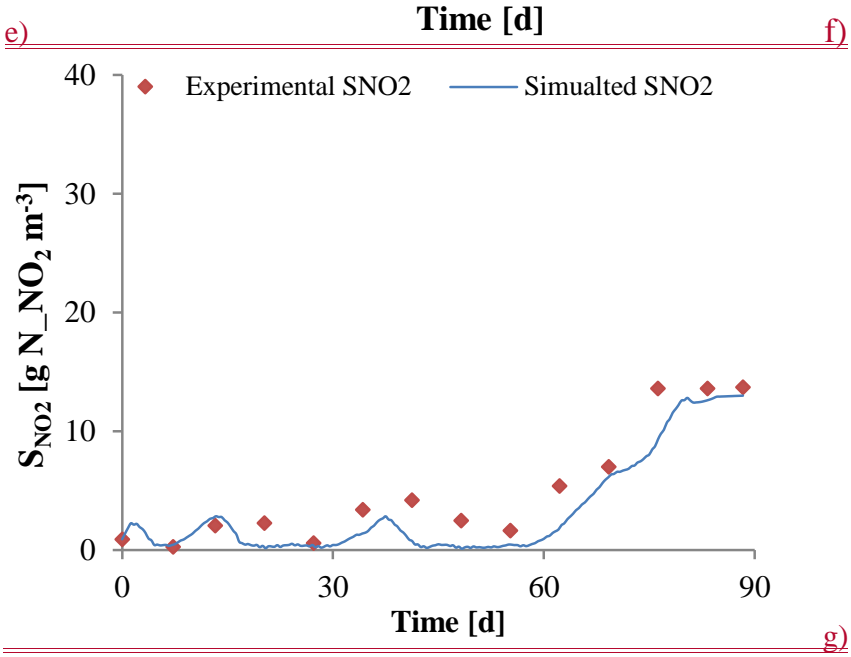



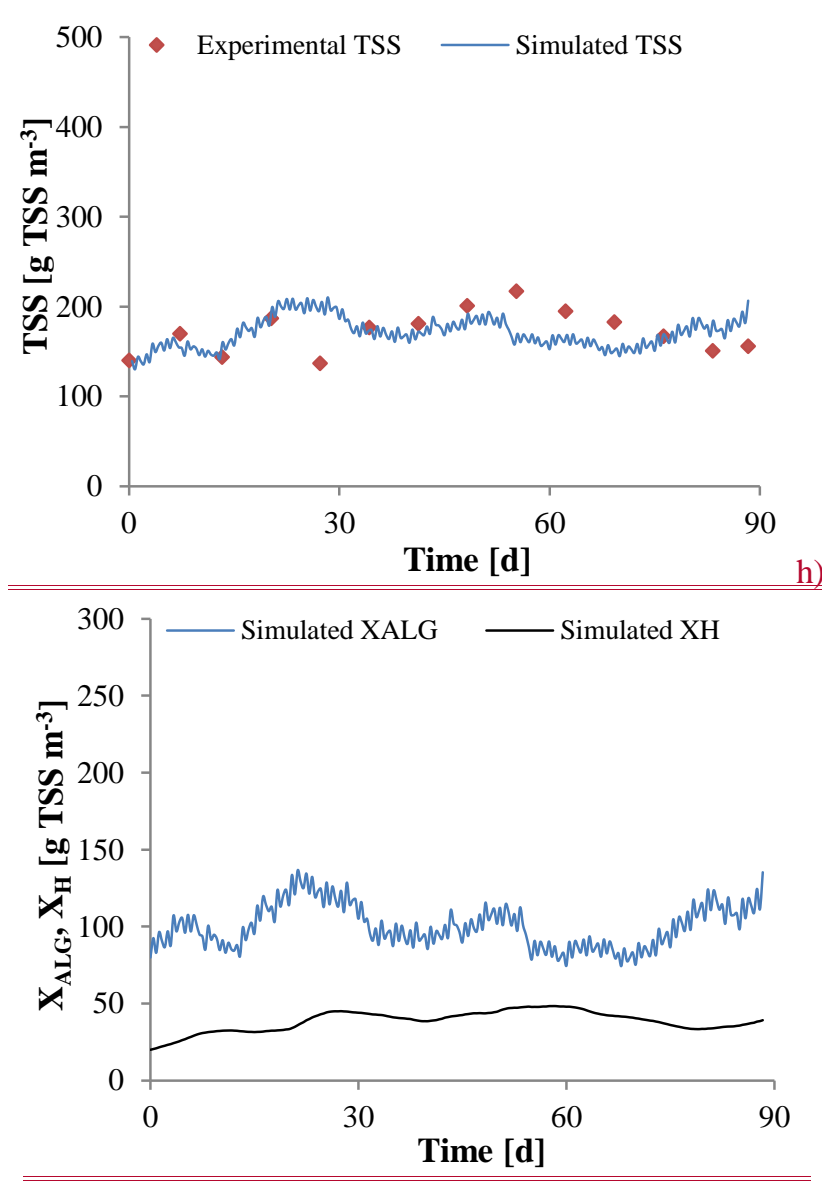


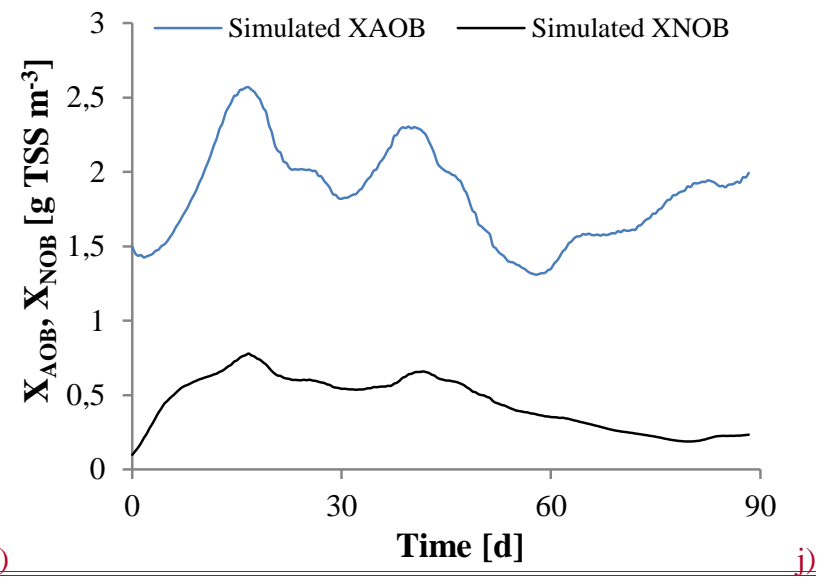

593

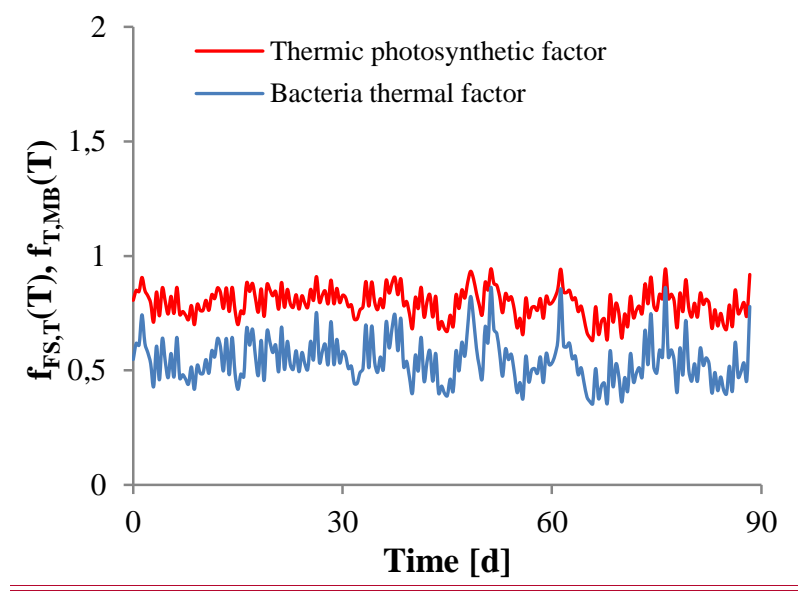

594 Fig. 5. Changes in experimental (red diamonds) and simulated (blue and black lines) a) pH, b) $\mathrm{S}_{\mathrm{O} 2}$, c) $\mathrm{S}_{\mathrm{HCO}}$, d) $\mathrm{S}_{\mathrm{NH} 4}$ 595 e) $S_{\mathrm{NO3}}$, f) $\mathrm{S}_{\mathrm{NO2}}$, g) TSS, h) $\mathrm{X}_{\text {ALG }}$ and $\mathrm{X}_{\mathrm{H}}$, i) $\mathrm{X}_{\mathrm{AOB}}$ and $\mathrm{X}_{\mathrm{NOB}}$ concentrations and j) changes in the values of $\mathrm{f}_{\mathrm{FS}, \mathrm{T}}(\mathrm{T})$ 596 and fT.MB (T) factor over the Period II (November 10th, 1993 - February 8th, 1994) in the HRAP8d. Note that in a) 597 and b) values were measured at 9:00 $\mathrm{AM} \pm 1$ hour and 2:00 $\mathrm{PM} \pm 1$. All other values measured at 2:00 $\mathrm{PM} \pm 1$ hour. 598 Higher values of $\mathrm{pH}$ and $\mathrm{SO}_{\mathrm{O} 2}$ observed at 2:00 PM \pm 1 hour. S $\mathrm{NO3}$ and $\mathrm{S}_{\mathrm{NO} 2}$ concentrations were not detected in influent 599 wastewater. 

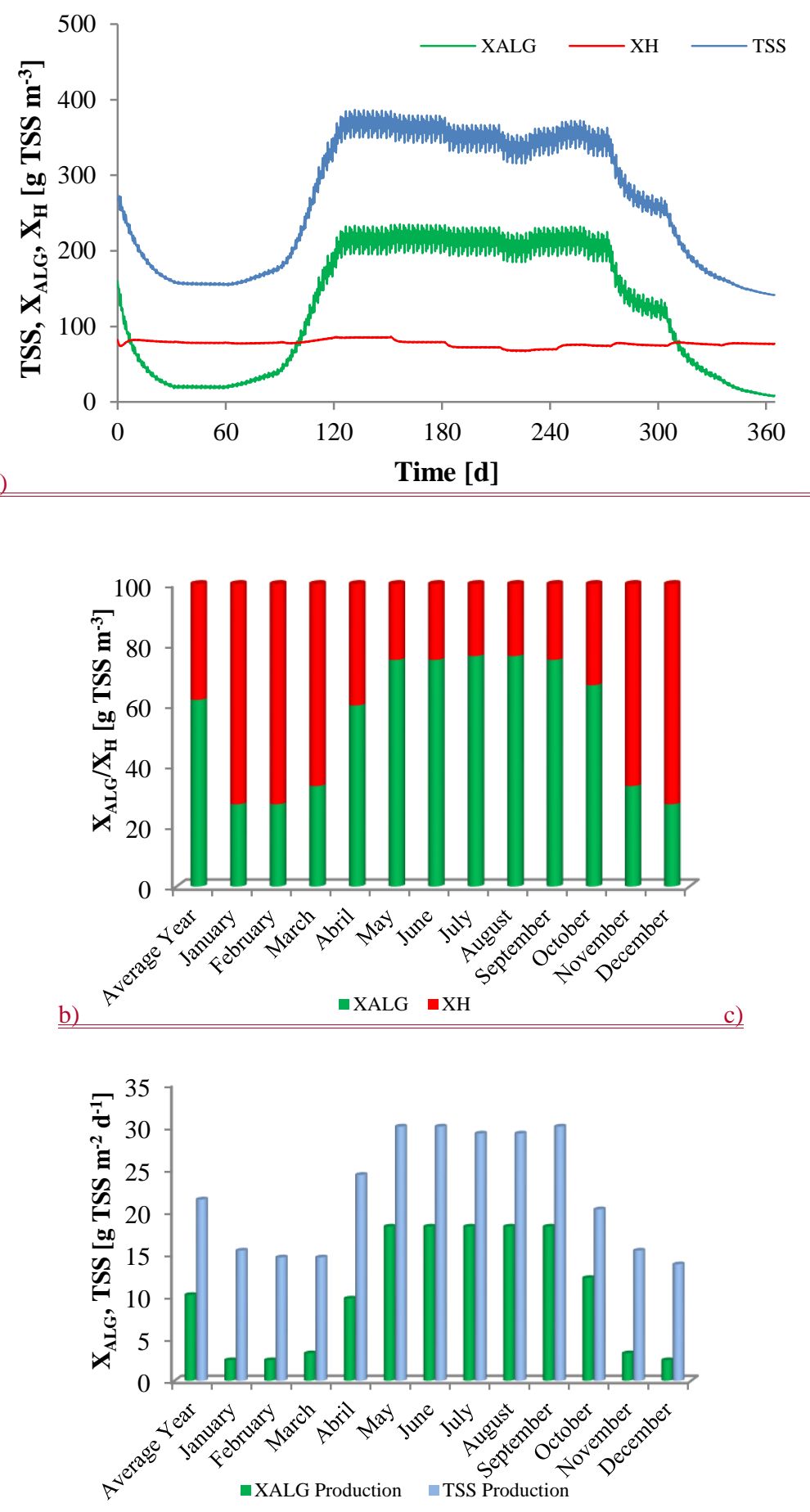

603

604 Fig. 6. a) Simulated TSS (blue line), $\mathrm{X}_{\mathrm{ALG}}$ (green line) and $\mathrm{X}_{\mathrm{H}}$ (red line) concentration over a year (from January to 605 December) in HRAP 4 d. Average annual and monthly b) $\mathrm{X}_{\text {ALG }}$ and $\mathrm{X}_{\mathrm{H}}$ concentration proportion, and c) $\mathrm{X}_{\mathrm{ALG}}$ and TSS 606 in $\mathrm{HRAP}_{4 \mathrm{~d}}$. 


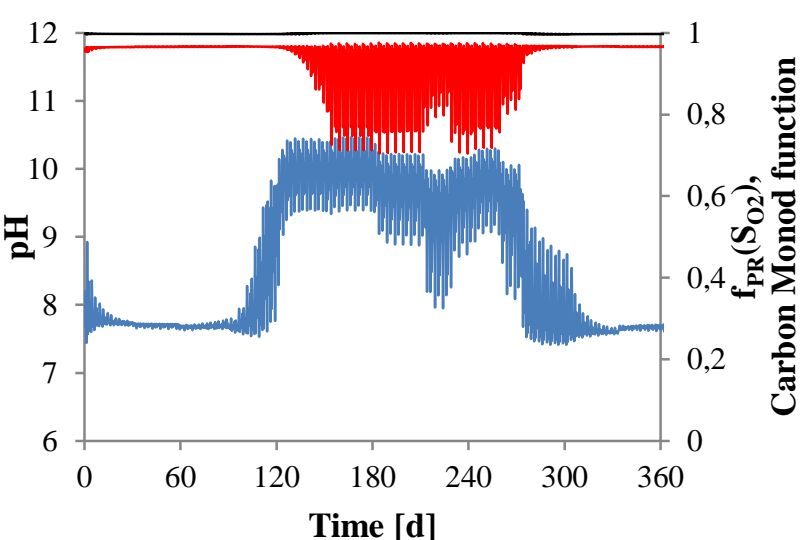

608

a) $\mathrm{pH} \longrightarrow$ Carbon Monod factor - Photorespiration factor $\mathrm{b})$

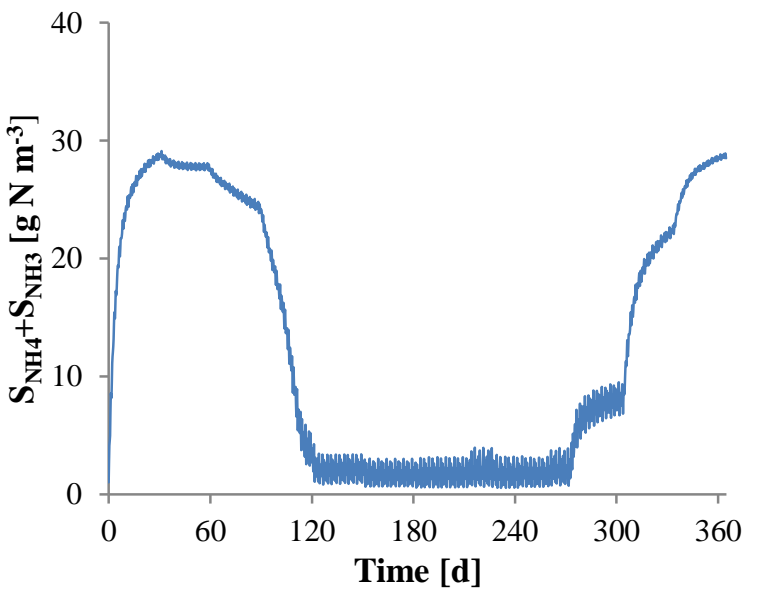

609

610 Fig. 7. Changes in a) $\mathrm{pH}, \mathrm{f}_{\mathrm{pR}}\left(\mathrm{S}_{\mathrm{O} 2}\right)$ and carbon Monod function value and b) $\mathrm{S}_{\mathrm{NH} 4}+\mathrm{S}_{\mathrm{NH} 3}$ concentration over a year in $611 \underline{\text { HRAP }}_{4}$.

612

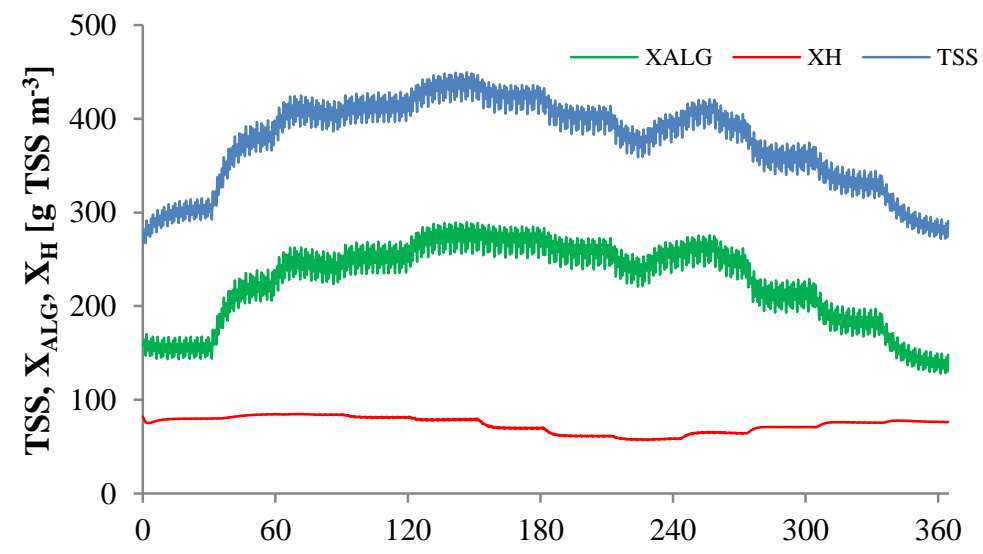

a)

Time [d] 


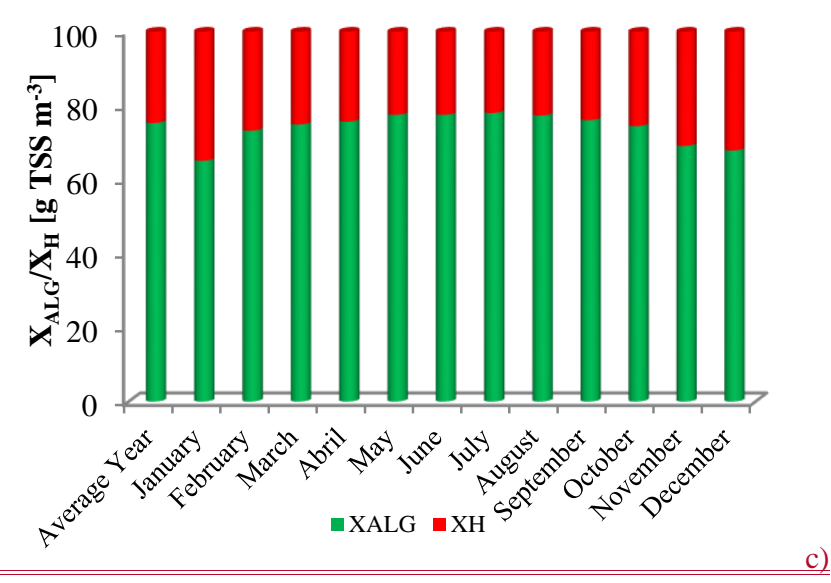

615

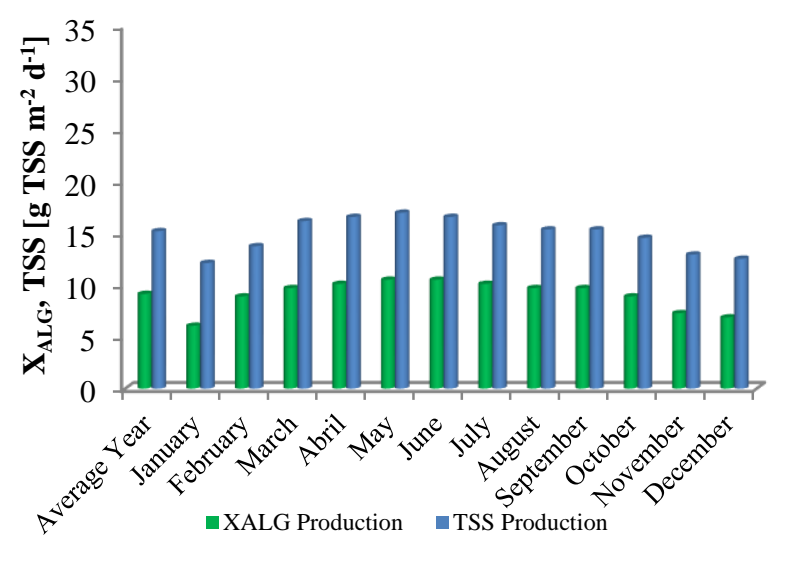

616 Fig. 8. a) Simulated TSS (blue line), $\mathrm{X}_{\text {ALG }}$ (green line) and $\mathrm{X}_{\mathrm{H}}$ (red line) concentration over a year (from January to 617 December) in HRAP 8 . Average annual and monthly b) $\mathrm{X}_{\underline{A L G}}$ and $\mathrm{X}_{\mathrm{H}}$ concentration proportion, and c) $\mathrm{X}_{\mathrm{ALG}}$ and TSS 618 in HRAP ${ }_{8 d .}$

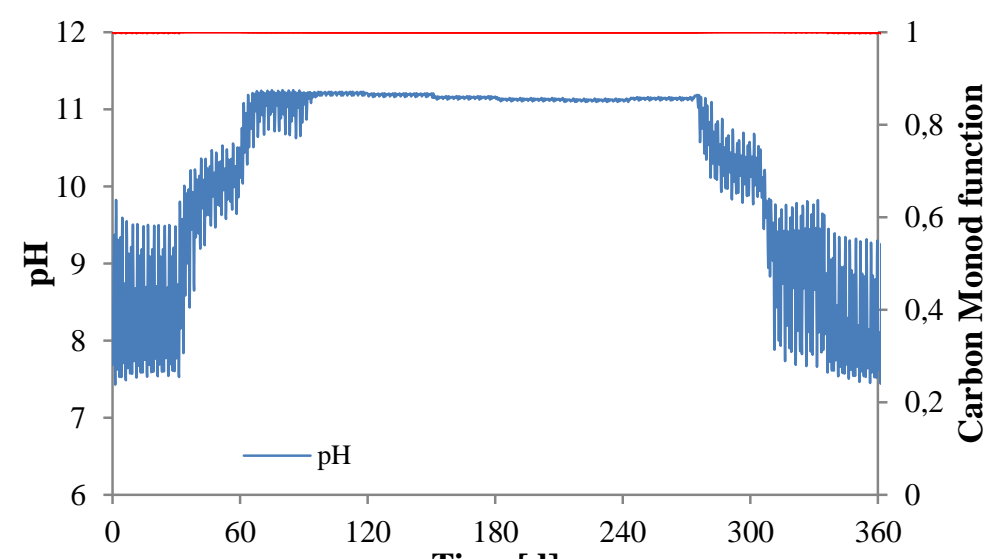

a)

Time [d] 


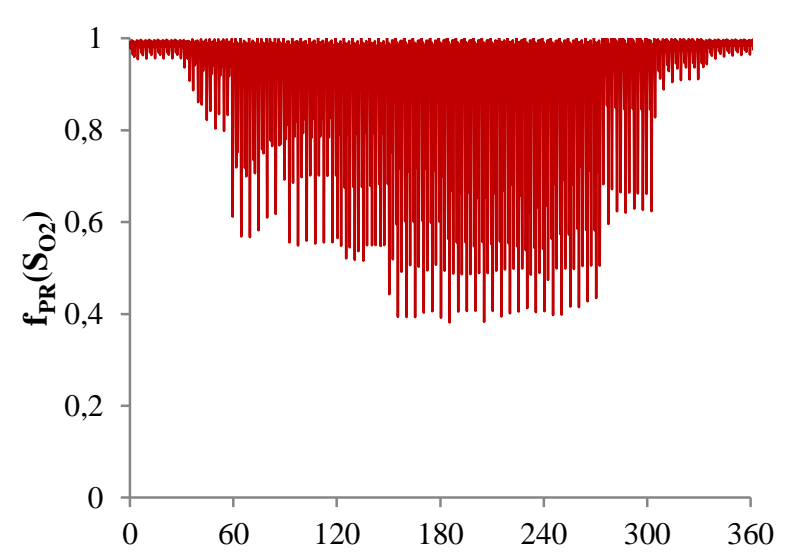

b)

Time [d]



621

622 Fig. 9. Changes in a) $\mathrm{pH}$ value and carbon Monod function, b) ( $\mathrm{f}_{\mathrm{PR}}\left(\mathrm{S}_{\mathrm{O} 2}\right)$ ) values and c) $\mathrm{S}_{\mathrm{NH} 4}+\mathrm{S}_{\mathrm{NH} 3}$ concentrations 623 over a year in HRAP ${ }_{\text {8d. }}$

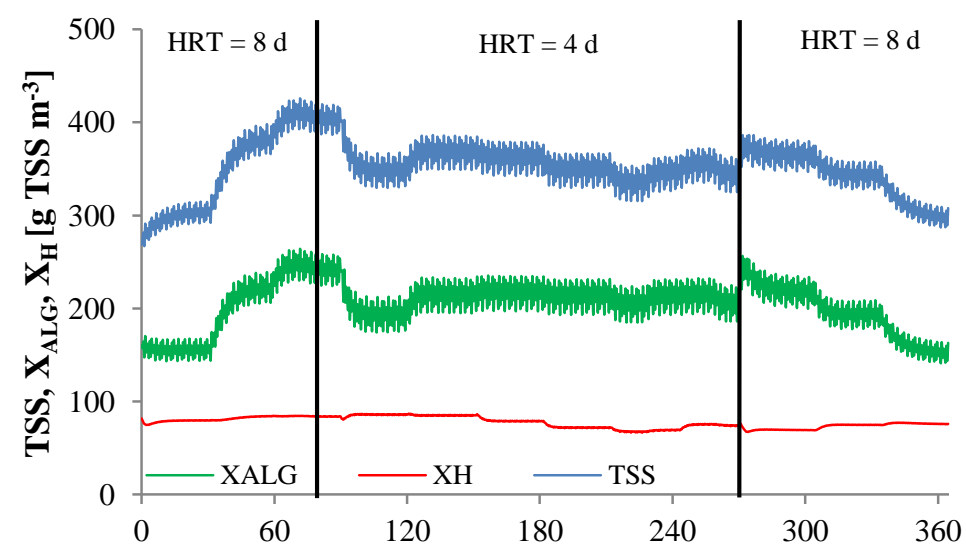



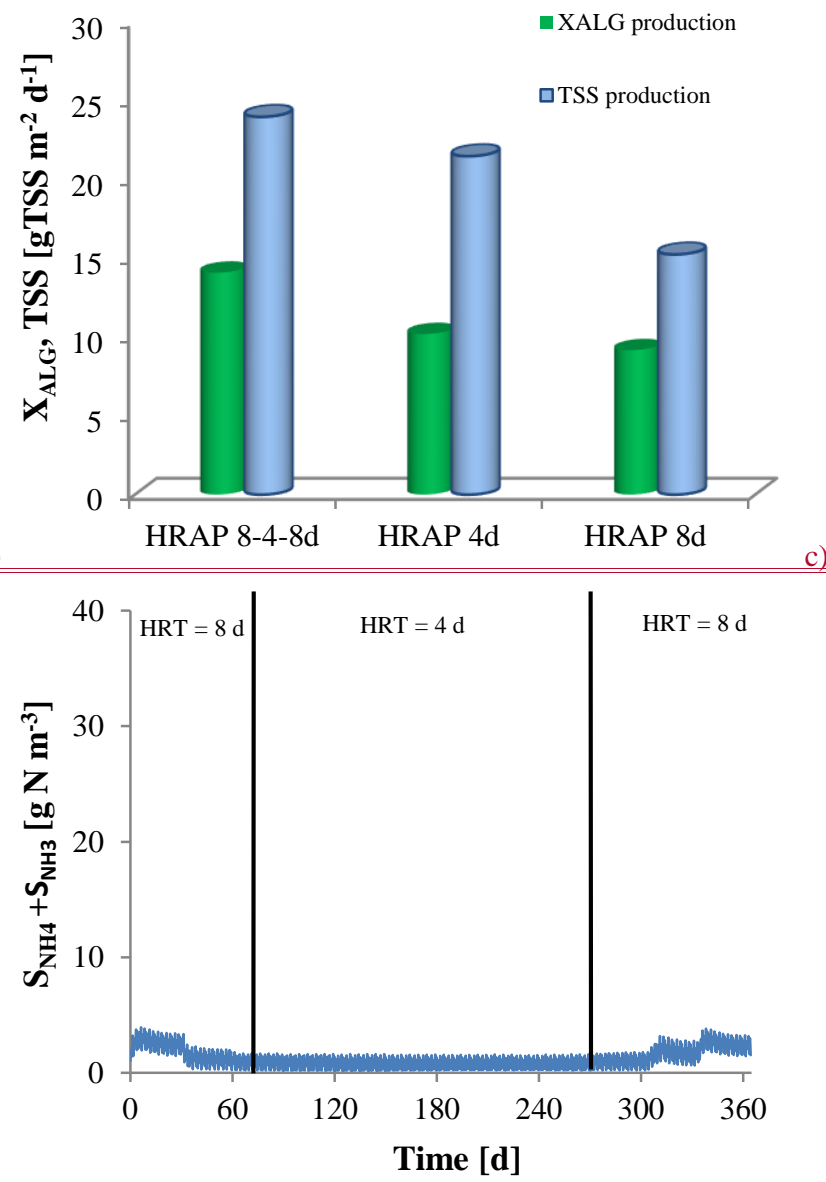

627 Fig. 10. a) Simulated TSS (blue line), $X_{\underline{A L G}}$ (green line) and $X_{H}$ (red line) concentration over a year (from January to 628 December) in HRAP $\underline{\underline{8-48 d}}$. Vertical black lines indicate HRT change. b) Comparison of average annual X $\underline{\underline{A L G}} \underline{\underline{a n d}}$ TSS 629 production over a year as function of different HRT operating strategies and c) Changes in $\mathrm{S}_{\mathrm{NH} 4}+\mathrm{S}_{\mathrm{NH} 3}$ concentration 630 over a year in HRAP ${ }_{8-4-8 \mathrm{~d}}$. Vertical black lines indicate the change of HRT. 